PNL-10149

UC-249

\title{
Possible Global Environmental Impacts of Solid Waste Practices
}

\author{
M. M. Davis \\ G. M. Holter \\ T. J. DeForest \\ D. C. Stapp \\ J. C. DiBari ${ }^{(2)}$
}

September 1994

Prepared for

the U.S. Department of Energy

under Contract DE-AC06-76RLO 1830

Pacific Northwest Laboratory

Richland, Washington 99352

(a) Heritage College, Toppenish, Washington. 


\section{DISCLAIMER}

This report was prepared as an account of work sponsored by an agency of the United States Government. Neither the United States Government nor any agency thereof, nor any of their employees, make any warranty, express or implied, or assumes any legal liability or responsibility for the accuracy, completeness, or usefulness of any information, apparatus, product, or process disclosed, or represents that its use would not infringe privately owned rights. Reference herein to any specific commercial product, process, or service by trade name, trademark, manufacturer, or otherwise does not necessarily constitute or imply its endorsement, recommendation, or favoring by the United States Government or any agency thereof. The views and opinions of authors expressed herein do not necessarily state or reflect those of the United States Government or any agency thereof. 


\section{DISCLAIMER}

Portions of this document may be illegible in electronic image products. Images are produced from the best available original document. 


\section{Executive Summary}

Pollutants resulting from the management of solid waste have been shown to affect the air, land, oceans, and waterways. In addition, solid wastes have other, more indirect impacts such as reduction in feedstocks of natural resources, because useful materials are disposed of rather than recycled. The objective of this study is to evaluate solid waste management practices that might have negative implications on the global environment and develop recommendations for reducing such impacts. Recommendations identifying needed changes are identified that will reduce global impacts of solid waste practices in the future.

The scope of this study includes the range of non-hazardous solid wastes produced within our society, including municipal solid waste (MSW) and industrial solid waste (ISW), as well as industry-specific wastes from activities such as construction, demolition, and landclearing. Industrial hazardous solid wastes, industrial waste waters and sludge, radioactive wastes, infectious or medical wastes, and mixtures of these are not included within this study.

Although development of the best available technologies and practices in waste management and waste regulations in industrialized countries over the past decade has drastically reduced environmental impacts related to solid waste management, potential areas of concern remain for industrialized countries. The more serious concern, however, is prevention and mitigation of environmental impacts from solid waste practices for less-developed countries (LDCs) and industrializing nations.

The following key recommendations are presented and justified in this report:

- Technology Transfer and Support to Industrializing Countries - To spare industrializing countries, and thus the global environment, from having to learn the same painful lessons learned by industrialized countries from inadequate past waste disposal practices, control technologies and strategies practiced in industrialized countries must be transferred to industrializing countries.

- Industrial Solid Waste Management - In the U.S., extensive environmental assessments and waste characterization data are needed from industrial waste sites to determine their potential for existing or future environmental contamination. The 1988 EPA report on solid waste in the U.S. (EPA 1988) indicates that increased monitoring of industrial Subtitle D wastes and waste facilities is needed to fill remaining data gaps and conduct meaningful assessment of human and environmental risk and for developing appropriate regulatory controls.

- Landfill Gas Emissions - Timely promulgation of the proposed amendments to the Clean Air Act would reduce the atmospheric impacts from landfill gas emissions in the U.S.; however, similar efforts are not expected worldwide. Successful removal and destruction efficiency of pollutants in landfill gas is highly dependent on adequate venting systems and collection and flaring or methane conversion equipment. 
- Waste Combustion Emissions - Current research and development efforts to assess risks from waste combustion emissions should be continued. These efforts will not only provide the basis for determining the level of impacts, but will also help make appropriate decisions about the need to develop improved, more cost-effective air pollution control devices.

- Land Disposal Leachate Control - Technology transfer to LDCs on the application of liners, collection systems, monitoring systems, and corrective action provisions are important steps to ensure minimal environmental impacts. Increased regulations for use of liners and leachate collection systems for ISW land disposal units would help mitigate future leachate releases.

- Inadequate Past Waste Disposal Practices - Improved response mechanisms to detrimental impacts from past practices are necessary. Clean-up treatment strategies and technologies are often extremely expensive and need to be further developed for more efficient and cost-effective remediation.

- Social Health and Welfare Related to Solid Waste Practices - Extending, expanding, and improving waste collection and safe disposal services in LDCs is essential to gain control over waste-related environmental and health problems (UNCED, Agenda 21, p. 13). Technology transfer of MSW and ISW control technology to LDCs and industrializing nations will also help to avoid the various human health hazards associated with solid waste management.

- $\quad$ Recycling Technology and Source Reduction - Research and development for sustainable operation and increased deployment and effectiveness of recycling programs should continue. The success of recycling is highly dependent on further development of markets, technologies and incentives for using recycled products. Tax incentives, encouragement of investment in technology development, and other economic incentives to source reduce and to recycle should be further investigated and implemented, especially for industrialized countries. Product price structures should be reevaluated to ensure products reflect more of the life-cycle costs of raw materials, manufacture, and disposal.

Most solid waste management decisions continue to be made and implemented at very local levels, predominantly with a short-term focus to respond to relatively immediate pressures of landfill shortages, funding problems, political considerations, and the like. This rush to address immediate local problems often detracts the level of effort devoted to mitigating and preventing environmental impacts, either short- or long-term, at the national or global level resulting from solid waste management practices. This report is a start toward identifying these deficiencies so that they can be appropriately addressed. 


\section{Contents}

Executive Summary $\ldots \ldots \ldots \ldots \ldots \ldots \ldots \ldots \ldots \ldots \ldots \ldots \ldots \ldots \ldots$

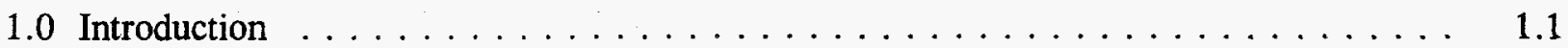

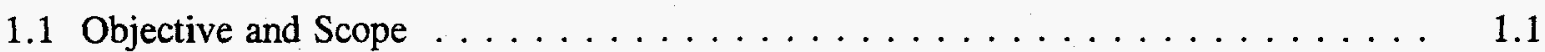

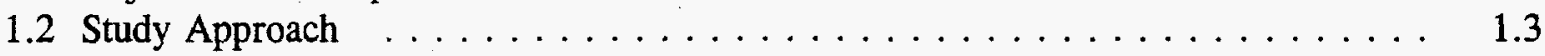

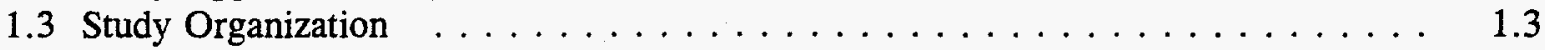

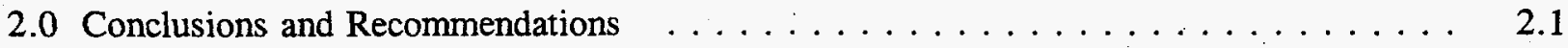

2.1 Technology Transfer and Support to Industrializing Countries $\ldots \ldots \ldots \ldots$

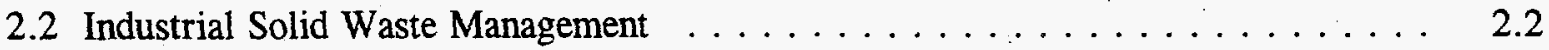

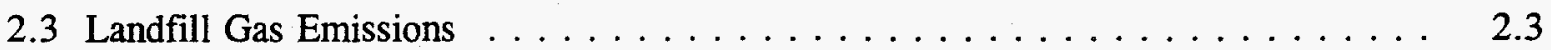

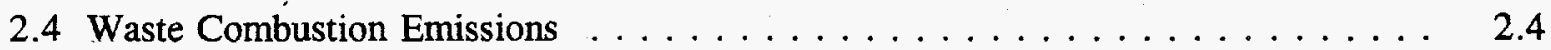

2.5 Land Disposal Leachate Control $\ldots \ldots \ldots \ldots \ldots \ldots \ldots \ldots \ldots$

2.6 Inadequate Past Solid Waste Disposal Practices $\ldots \ldots \ldots \ldots \ldots$

2.7 Social Health and Welfare Related to Solid Waste Practices $\ldots \ldots \ldots \ldots$

2.8 Recycling Technology and Source Reduction $\ldots \ldots \ldots \ldots \ldots \ldots$

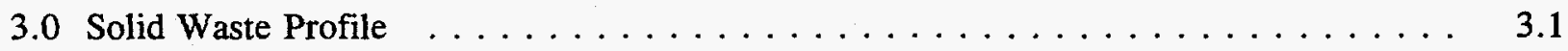

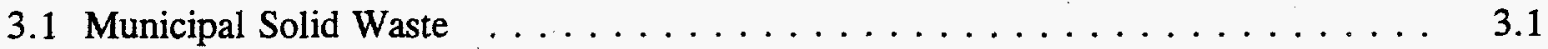

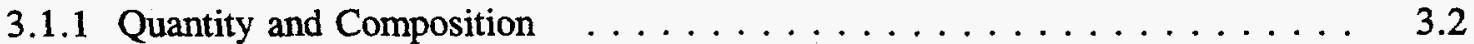

3.1.2 Disposal Options and Technologies . . . . . . . . . . . 3.3

3.1.3 Waste Management and Regulation in the U.S. . . . . . . . . . . . 3.4

3.2 Industrial Solid Waste $\ldots \ldots \ldots \ldots \ldots \ldots \ldots \ldots \ldots$

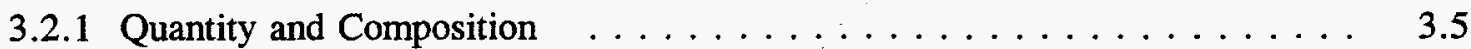

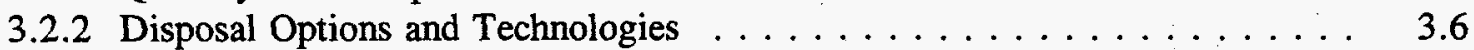

3.2.3 Waste Management and Regulation in the U.S. . . . . . . . . . 3.6

4.0 Impacts and Trends from Municipal Solid Waste Practices $\ldots \ldots \ldots \ldots \ldots$ 
4.1 Pollution $\ldots \ldots \ldots \ldots \ldots \ldots \ldots \ldots \ldots \ldots \ldots \ldots \ldots \ldots \ldots \ldots$

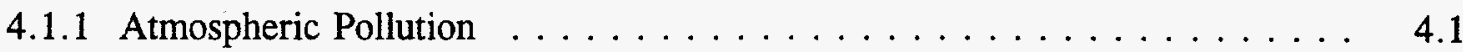

4.1 .2 Land and Water Pollution $\ldots \ldots \ldots \ldots \ldots \ldots \ldots \ldots$

4.2 Human Health and Safety $\ldots \ldots \ldots \ldots \ldots \ldots$

4.2.1 Public Health and Safety in Industrialized Countries f . . . . . . . . 4.6

4.2.2 Worker Health and Safety in Industrialized Countries $\ldots \ldots \ldots \ldots$. . . . 4.8

4.2.3 Human Health and Safety in Less-Developed Countries . . . . . . . . . . 4.9

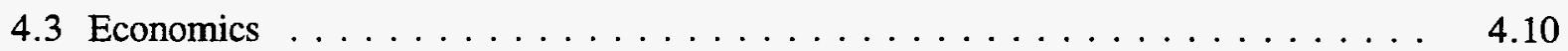

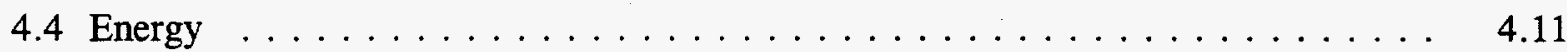

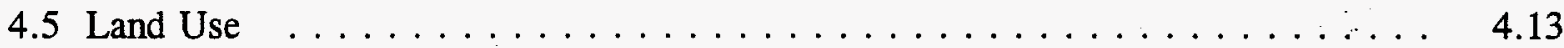

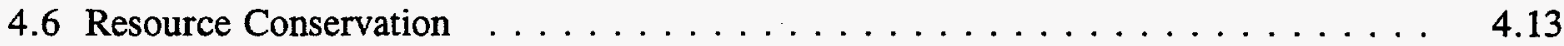

4.7 Source Reduction $\ldots \ldots \ldots \ldots \ldots \ldots \ldots \ldots \ldots \ldots \ldots \ldots$

5.0. Impacts and Trends of Industrial Solid Waste Practices $\ldots \ldots \ldots \ldots \ldots$

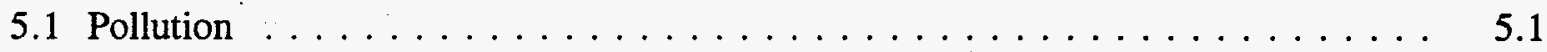

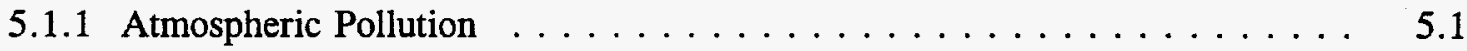

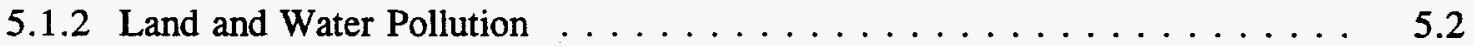

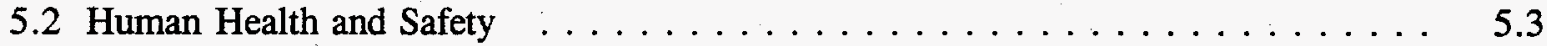

5.2.1 Public Health and Safety in Industrialized Countries . . . . . . . . . . . . 5.3

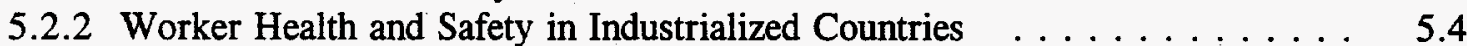

5.2 .3 Human Health and Safety in Less-Developed Countries . . . . . . . . 5.4

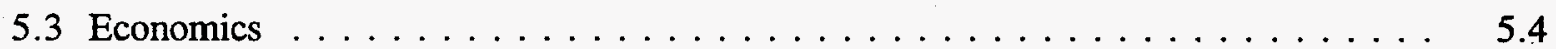

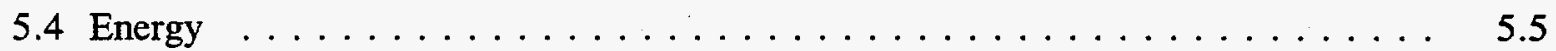

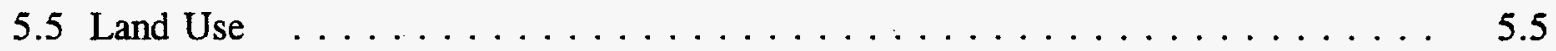

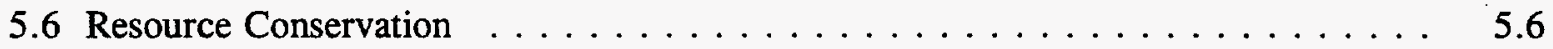

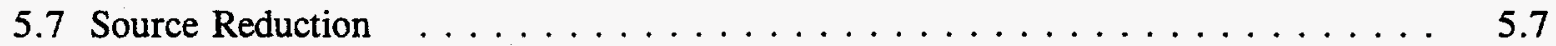

6.0 References and Bibliography $\ldots \ldots \ldots \ldots \ldots \ldots \ldots \ldots \ldots \ldots \ldots$ 


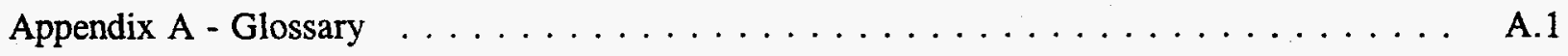

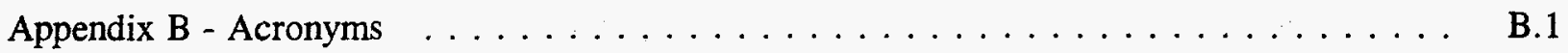

Appendix $\mathrm{C}$ - Moderate Risk Waste $\ldots \ldots \ldots \ldots \ldots \ldots \ldots \ldots \ldots \ldots \ldots$

Figures

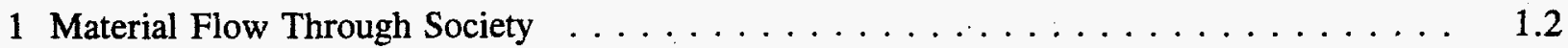

2 Typical Composition of U.S. MSW Stream $\ldots \ldots \ldots \ldots \ldots \ldots \ldots \ldots$

\section{Tables}

1 Results of 1986 EPA Survey on Industrial Solid Waste Sources $\ldots \ldots \ldots . \ldots$

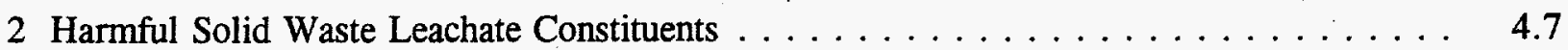

3 Energy Saved by Manufacturing from Recycled Products $\ldots \ldots \ldots \ldots \ldots \ldots$ 


\subsection{Introduction}

Solid wastes are inevitable byproducts of human activities. Every segment of our society generates solid wastes, and the activities generating the wastes and resulting waste compositions are very diverse. These diverse waste products represent a complex potential threat to the environment. Continued population growth and trends toward greater urbanization are resulting in increased waste quantities, thus creating potential for more serious problems in the future.

The complexity and scope of the solid waste problem have not been fully recognized and addressed by our society, for a variety of reasons. This has resulted in the lack of a coherent, integrated approach to solving present waste problems and/or preventing future ones. Instead, approaches to waste management, waste minimization, and waste regulation have been responsive (or reactive) to particular problems or problem symptoms, and compartmentalized to match the specific responsibilities of the particular groups involved. In particular, most solid waste management decisions continue to be made and implemented at very local levels, predominantly with a short-term focus to respond to relatively immediate pressures of landfill shortages, funding problems, political considerations, and the like. In this rush to address immediate local problems, little consideration is being given to potential impacts, either short- or long-term, at the national or global level resulting from solid waste management practices. More and more, the cumulative impacts from local decisions concerning solid waste management are beginning to manifest themselves in broader, longer-term impacts than are being addressed by the decision-makers or, at the very least, are presenting a greater and greater potential for such impacts (Holter and Stapp 1993).

\subsection{Objective and Scope}

The objective of this study is to evaluate current solid waste practices and management, and the associated long-term trends, that might have implications on the global environment, to qualitatively identify the environmental implications of these practices and trends. Pollutants from solid waste affect the air, land, oceans, and waterways. In addition, solid wastes have other, more indirect impacts, such as the reduction in feedstocks of natural resources because useful materials are disposed of rather than recycled. As part of this study, it is necessary to define the linkages between local solid waste practices and the macro-level impacts they may cause. The results of this report are intended to be used to develop recommendations for changes that will reduce the impacts of solid waste practices in the future. Based on the implications that are identified, some preliminary recommendations are provided for improvements in solid waste practices and needs for further study.

This study is not an exhaustive catalog of all possible impacts from solid waste practices. However, it provides further definition on the relative severity and importance of the most significant of these impacts.

The scope of this study includes the range of non-hazardous solid wastes produced within our society, including municipal solid waste (MSW) and industrial solid waste (ISW), as well as industry-specific wastes such as those from construction, demolition and landclearing (CDL). Industrial hazardous solid wastes, industrial waste waters and sludge, radioactive wastes, infectious or medical wastes, and mixtures of these are not included within this study; these wastes are the subjects 
of considerable previous study and are already seen as having the potential to cause large-scale, broad-based impacts if not properly managed.

Waste management practices, technologies, and related regulations in the U.S. are the primary focus in this study, with the recognition that most industrialized nations employ similar practices, technologies, controls, and regulations. However, many industrializing countries fall drastically short of implementing or planning for use of these best available technologies (BAT) or best available practices and, thus, the potential for significant impacts is even greater in these countries.

The flow of materials through society is depicted in Figure 1 (Holter and Stapp 1993). Note that solid waste materials can be managed in several different ways, and that these different management options imply differing impacts as a result. Thus, it is important to consider all of these management options, as well as the trade-offs between them.

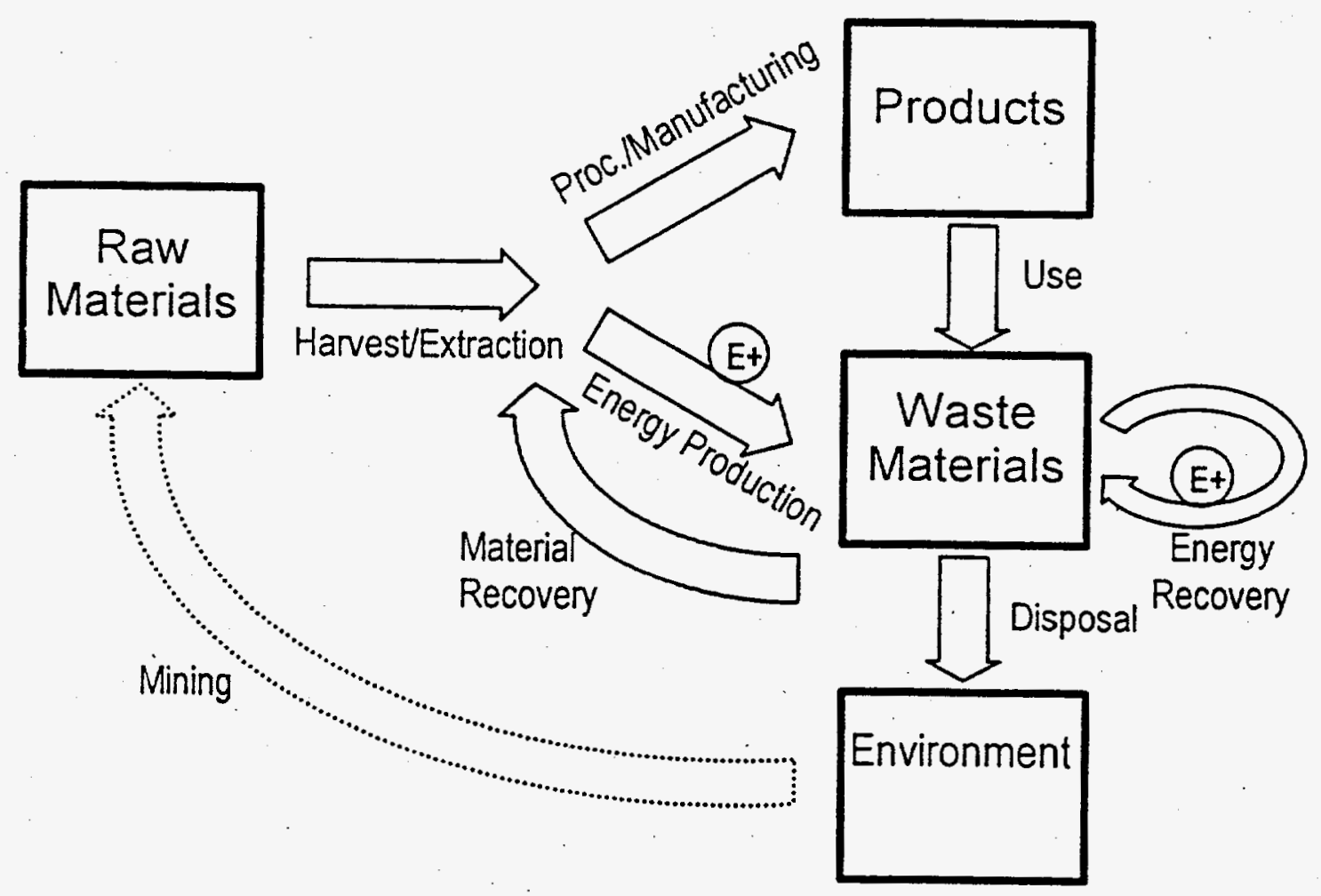

Figure 1. Material Flow Through Society 


\subsection{Study Approach}

This study is based primarily on a review of pertinent literature. This review is supplemented by several brainstorming sessions held with staff at the Pacific Northwest Laboratory (PNL), and discussions with respected experts in the solid waste field, on the subject of trends relating to solid waste practices. The information from these sources was then evaluated to arrive at the conclusions and recommendations presented here.

Several different types of impacts can result from solid waste practices, including:

- direct impacts resulting from the amounts of wastes produced, managed, and disposed (e.g., land-use impacts, transportation impacts);

- direct impacts resulting from constituents contained in the wastes (e.g., mercury in batteries, lead in paint residues); and

- indirect impacts (e.g., waste of materials or other resources) relating to solid waste practices.

In addition, different levels of global severity of these direct and indirect impacts can occur. Global impacts include impacts that are global in nature as well as impacts that when individually considered are more local or regional problems, but when considered collectively (cumulatively), become a global issue. Air pollution resulting from waste incineration is an example of a true global impact. The contaminants are rapidly dispersed and can reduce the air quality hundreds or even thousands of miles from the source. The second type of impact is represented by leachate contaminating groundwater supplies. Although the potential for contaminated groundwater affecting areas outside the surrounding region is small, the combined impact of contaminating a large number of aquifers has global implications. Even if a particular groundwater source can be managed on a local level, the surrounding communities may not have the resources or expertise to deal with the problem. Furthermore, because the problem is considered a local one, the widespread nature of the impacts may not be recognized until after considerable deterioration has occurred.

Impacts in each category and level are considered in this study.

The identification of impacts is intended to provide an ability to consider and address impacts before they become more severe. This approach is somewhat different than many of society's past responses to environmental problems, where action was only taken to address problems once the impacts associated with them became quite apparent. However, the approach advocated here is intended to provide the flexibility to consider options and alternatives while there is still some time available for consideration.

\subsection{Study Organization}

Analysis and conclusions resulting from this investigation are summarized in Section 2, with some preliminary recommendations concerning possible improvements in solid waste practices and needs for further study. Linkage of local solid waste impacts to macro-level impacts is addressed in Section 2. A general profile of solid wastes is provided in Section 3. Current impacts and trends 
resulting from MSW practices and ISW practices are described in more detail in Sections 4 and 5. References and bibliographical information are provided in Section 6. A glossary of terms is included in Appendix A, and acronyms are provided in Appendix B. Appendix C contains a supplemental discussion on moderate risk waste (MRW) and hazardous household waste (HHW).

Throughout this study, emphasis is placed on direct and cumulative impacts with little in-depth discussion of lesser, indirect impacts. Issues, impacts, and trends are discussed by waste management method, as applicable, in the following order: landfilling, waste combustion, recycling, composting, waste transportation. 


\subsection{Conclusions and Recommendations}

Conclusions and recommendations were drawn from the information presented in subsequent sections of this report, and are presented within this section. These recommendations are not intended to be a cure-all for the giobal issues of the solid waste problem. However, they are considered important in mitigating the situation and minimizing future environmental problems. The major issues are briefly discussed here. Further supporting information is provided in Sections 4 and 5.

The key questions addressed in this section are:

- Are impacts from solid waste practices major?

- Are these impacts global or broad-reaching?

- Are these impacts localized with limited importance, or do they collectively/accumulatively become important?

Solid waste is an international problem. At least $60 \%$ of the countries who participated in the 1992 United Nations Conference on Environment and Development (UNCED) held in Brazil reported that solid waste disposal was among their biggest environmental concerns (Hammond 1993, p. 90). Thus, at least for these countries, environmental problems associated with solid waste are of the same relative importance as other types of environmental impacts. The action plan resulting from UNCED, called "Agenda 21," recommends various objectives, tools, and processes for integrating environmental and economic considerations into decision making. The recommendations with respect to solid waste management are considered by the authors to be important steps toward controlling global environmental impacts from worldwide solid waste practices.

Although development of best available technologies and practices in waste management and waste regulations in industrial countries over the past decade has drastically reduced environmental impacts related to solid waste management, potential areas of concern remain for industrialized countries. The more serious concern, however, is prevention and mitigation of environmental impacts from solid waste practices for less-developed countries (LDCs) and industrializing nations. It is also questionable whether controls on industrial solid waste (ISW) management currently provide adequate protection for the environment. However, in these industrialized countries with well established solid waste practices, the potential impacts from solid waste are not perceived to be as important as other, more critical environmental concerns (e.g., air pollution, acid rain, and direct pollution of surface waters).

\subsection{Technology Transfer and Support to Industrializing Countries}

The majority of countries and the world population exist in rapidly industrializing or LDCs which practice much less-controlled waste management than is typical of industrialized countries. Most industrializing countries and LDCs generally use crude disposal methods with few, if any, regulatory controls, and have little capital to devote to waste disposal and sanitation. This situation demands 
urgent attention and resources to devote to developing appropriate waste management practices as countries continue to industrialize.

Recommendations: To spare industrializing countries, and thus the global environment, from having to learn the same painful lessons learned by industrialized countries from inadequate past waste disposal practices, control technologies and strategies practiced in industrialized countries must be transferred to industrializing countries.

A key role for industrialized countries will be to provide financial and technological support to implement adequate waste management practices worldwide. Assessment of needs for industrializing countries would allow the proper mix of waste management controls for the level of industrialization, waste quantity and composition, demographic situation, environmental and economic considerations of each nation. It is far cheaper and less devastating to human health and the environment to proactively implement controls on waste handling and disposal to avoid problems rather than to react to problems once they occur and become apparent.

One mechanism for providing such assistance is through participation in the development of international standards for environmental management practices. Because compliance with such standards is important for nations that wish to participate in international trade, most countries will have strong incentives to respond to these evolving standards.

\subsection{Industrial Solid Waste Management}

Non-hazardous industrial solid waste is by far the largest quantity of solid waste, and quite possibly of greater potential concern to the environment than MSW because of the type, volumes and concentrations of the constituents. Nevertheless, the regulatory and environmental controls on nonhazardous ISW are considerable less stringent than those on MSW.

Part 257 of Subtitle D regulations establishes voluntary guidelines for state management plans to develop minimum standards pursuant to the Maximum Contaminant Levels (MCL) of the Safe Drinking Water Act (SDWA). These criteria appear to be incomplete, however, because they do not require engineering controls, air or groundwater monitoring or specify corrective action requirements if contamination occurs (Office of Technology Assessment 1992, p. 14). State Implementation Plans resulting from Subtitle D vary greatly, and some state plans may have more stringent regulations. This results in a broad range of control application for ISW disposal.

Recommendations: In the U.S., extensive environmental assessments and waste characterization data are needed from industrial waste sites to determine their potential for existing or future environmental contamination. The EPA 1988 report on Solid Waste in the U.S. indicates that increased monitoring of industrial Subtitle D wastes and waste facilities is needed to fill remaining data gaps and conduct meaningful assessment of human and environmental risk and for developing appropriate regulatory controls.

Environmental controls and monitoring have probably increased over the past decade due to fear of future Superfund liability, but the frequency and stringency of controls varies among different states and industries. Rather than blanket requirements for all ISW land disposal 
units, Dernbach (1990) suggests that ISW disposal requirements such as landfill design for liners and leachate collection be based on the characteristics of the ISW and method of disposal. Lessons learned from establishing environmental and regulatory controls on MSW and hazardous waste management provide significant opportunities to rationalize ISW management programs to address environmental protection on a multi-media basis.

Despite any deficiencies, management of ISW in the U.S. and other industrialized countries is often far better than that practices in industrializing countries and LDCs. Thus, there is a significant opportunity to transfer technology to these other countries to improve their practices. There are some notable efforts for countries to get together and share their problems and solutions to facilitate this type of technology transfer. As one example, the Pacific Basin Consortium for Hazardous Waste Management provides a forum for sharing information and experiences on the development and implementation of programs for dealing with hazardous wastes. The U.S. and other industrialized countries should continue to support programs such as this.

\subsection{Landfill Gas Emissions}

The quantity of unrecovered methane and the carbon dioxide generated from municipal solid waste landfills (MSWLF) are contributing to global warming. To put these gas emissions into perspective, landfills are estimated to contribute $16 \%$ of global methane releases to the atmosphere (World Resources 1994-95, p. 364.) Other sources estimate even higher percentages of total methane from landfills. Greenhouse emissions of carbon dioxide from landfills are minimal compared to other sources.

Some landfills collect landfill-generated methane in energy recovery systems. Other landfills flare off collected landfill gases, which transforms most of the gas constituents to carbon dioxide and water. The only U.S. regulations on landfill gas are for monitoring and control of migration of subsurface methane for concentrations above set explosion limits. No control of methane or non-methane organic compound (NMOC) releases from landfills is required.

This may soon change for larger landfills in the U.S. Proposed amendments to the Clean Air Act as published in the Federal Register on May 30, 1991 would require collection and removal of $98 \%$ of NMOCs and volatile organic compounds (VOCs). This would indirectly require removal and destruction of the methane as well. However, smaller U.S. landfills, landfills in other industrialized countries, and open dumps in industrializing countries and less-developed countries (LDCs) will not be bound to these requirements. 
Recommendations: Timely promulgation of the proposed amendments to the Clean Air Act would reduce the impacts from landfill gas emissions. Successful removal and destruction efficiency is also highly dependent on adequate venting systems and collection and flaring or methane conversion equipment.

Successful technology transfer to LDCs would also facilitate reduction of such emissions worldwide.

\subsection{Waste Combustion Emissions}

Waste combustion is an attractive technology for handling many types of solid wastes because it significantly reduces waste volume and can provide useable energy. Air pollution control devices utilized at waste combustion facilities in most industrialized countries offer $98 \%$ or higher control and removal efficiency of toxic or harmful emissions. However, some trace pollutants are still released, posing potential risks to human health and contributing to acid rain and smog.

Air pollution control in municipal waste combustion (MWC) does not remove all dioxins, furans, acid gases and other trace pollutants from the exhaust gas. Both the EPA and state agencies have made control of dioxins and furans a high priority. Studies are still underway on health and environmental risks of current emission levels of dioxins, acid gases and other pollutants from MWC.

Although the U.S., Japan, Germany and a few other industrialized nations utilize best available technologies for emission control, waste combustion facilities in other industrialized countries do not always meet such standards. And, many LDCs practice open burning as a disposal option, with little or no emission control. As a result, significant air pollution can result from waste combustion activities in many countries, although it is seldom the predominant source of air pollution in an area. Perhaps the largest source of such air pollution results from the open burning of vegetative wastes resulting from the large scale clearing of land in developing countries (e.g., in the Amazon basin); such cases produce wide-spread air pollution, simultaneous with the other major environmental impacts resulting from these practices.

Recommendations: Current R\&D efforts to assess risks from waste combustion emissions should be continued. These efforts will not only provide the basis for determining the level of impacts, but will also help make appropriate decisions about the need to develop improved, more cost-effective air pollution control devices.

LDCs should be assisted in educating the populace to the hazards of open combustion. Appropriate technology transfer and economic assistance will help to improve practices in those countries.

\subsection{Land Disposal Leachate Control}

The durability and longevity of double leachate liner systems in MSWLFs is not infinite. If corrosive materials (e.g., from household hazardous wastes) do reach landfills, they can quickly corrode holes in liners and cause leachate to leak from the landfill. The leachate collection and 
monitoring equipment must then be relied on to detect leaks and prevent migration of the leachate. RCRA does provide for corrective action and remediation if groundwater contamination occurs beyond established limits, however, it would be better to be able to prevent contamination altogether.

Many ISW waste landfills and waste piles do not have provisions for leachate control or collection. For the small percentage of ISW disposal sites that do have liners, data indicates these offer limited protection from groundwater contamination from leachate.

Recommendations: Ensure technology transfer and application of liners, collection systems and monitoring systems to LDCs. Also ensure corrective action measures in regulations.

Increased regulations for and use of liners and leachate collection systems for ISW land disposal units would help mitigate future leachate releases.

\subsection{Inadequate Past Waste Disposal Practices}

Environmental impacts from inadequate waste disposal practices in the past were often ignored until drastic conditions ensued, requiring expedited and expensive attention to prevent further impacts and remediate existing impacts. This includes former municipal landfills or industrial land disposal units that received untreated hazardous or toxic wastes prior to effective land disposal restrictions of such waste. Many of these sites did not have leachate liners or gas collection systems, and had no restrictions on receipt of hazardous or liquid wastes. Hazardous solid industrial wastes are not intended to be discussed further in this study except with respect to inadequate past disposal practices.

Contaminated sites as a result of inadequate past practices have been designated for cleanup under the Superfund program. Superfund prioritizes clean up of the worst contaminated sites based on a National Priority List (NPL). The goal of Superfund is to ensure appropriate cleanup of these sites. Criteria for listing on the NPL is any formerly contaminated site that presents or is capable of presenting significant environmental or human health impacts. The Superfund program is criticized for many reasons, one being that millions of dollars are spent on legal fees to decide who will pay, creating lengthy delays for start of cleanup and wasting millions of dollars that could have been spent on actual cleanup or development of treatment technologies.

Former municipal landfills comprise about $20 \%$ of the sites listed on the Superfund (NPL) and many industrial land disposal sites have also been listed. A number of former and existing ISW land disposal units have not yet been investigated for inclusion on the NPL, thus the risk from these sites remains unknown. As many as 40,000 more former municipal landfills may still be contaminating or may have contaminated groundwater in the past (Hammond 1992). These sites may not pose the same level of danger associated with NPL sites but do pose environmental and health threats from contents such as hazardous household wastes including mercury batteries, CFC-containing appliances, and the like.

Poor documentation of past practices has resulted in lack of valuable information to characterize sites for proper treatment. The extent of this threat to human health and the environment from past practices is not totally clear at this time. 
Recommendation: Improved response mechanisms to detrimental impacts from past practices are necessary. Clean-up treatment strategies and technologies are often extremely expensive and need to be further developed for more efficient and cost-effective remediation.

Superfund reauthorization legislation is being debated by the EPA and environmental interest groups and organizations to improve the program, especially in the area of developing site cleanup standards, and to channel polluter's funds more on cleanup and development of cleanup technologies rather than wasting money (and time) for legal disputes and fees. Congress, scientists and policy makers should urgently address Superfund revisions and improvements to better facilitate cleanup of contaminated sites.

\subsection{Social Health and Welfare Related to Solid Waste Practices}

The open dumping of municipal solid waste and open burning of wastes in less-developed countries (LDC) pose very serious health threats to populations, many of whom are already susceptible to illness because of poor nutrition and reduced immune systems. Crude dumping allows for hazardous and toxic constituents such as mercury or lead from batteries to leach into local water supplies. Scavenging is also common at these open dumps, where people search for potentially valuable items and are exposed to a variety of hazards including toxic, sometimes explosive decomposition gases, sharp objects, and infectious wastes.

Pollution control for industrial solid waste practices has generally lagged behind industrialization. The U.S. has seen numerous examples of environmental contamination during its own industrialization (tailing piles from mining, abandoned landfills that are now Superfund sites, etc.). Industrializing countries will undoubtedly experience similar problems. With overall growth in industry, more toxic wastes are being produced and in much greater quantities. If left to develop without guidance from industrialized nations, these nations will almost certainly experience higher levels of environmental contamination than countries that industrialized in the late 19th and early 20th centuries. In addition, many industrializing countries have a much higher population density which tends to intensify environmental and health problems.

Recommendation: Extending, expanding, and improving waste collection and safe disposal services in LDCs is essential to gain control over waste related environmental and health problems (UNCED, Agenda 21, p. 13). Technology transfer of MSW and ISW control technology to LDCs and industrializing nations will also help to avoid the various human health hazards associated with solid waste management.

\subsection{Recycling Technology and Source Reduction}

Unsustainable patterns of production and consumption, especially in industrialized countries, are increasing the quantities and variety of environmentally persistent wastes (UNCED, Agenda 21, p. 2). Expanded source reduction and recycling (including composting) have the potential to greatly diminish the resulting impacts of solid waste generation. 
Recommendations: Research and development efforts for developing programs for sustainable operation and to support increased deployment and effectiveness of recycling programs need to be continued. The success of recycling is highly dependent on further development of markets, technologies, and incentives for using recycled products. Tax incentives, encouragement of investment in technology development, and other economic incentives to source reduce and to recycle should be further investigated and implemented, especially for industrialized countries. Product price structures should be reevaluated to ensure products reflect more of the life-cycle costs of raw materials, manufacture, and disposal.

Technologies developed for source reduction and recycling can also be transfered to LDCs to assist them in their efforts to address solid waste impacts. 


\subsection{Solid Waste Profile}

This section provides basic background information on current solid waste quantities, compositions, management and disposal options, and other practices specific to the U.S. The various environmental and health problems associated with solid waste in the U.S. arise largely due to the following factors:

- Increasing urbanization and consumerism, coupled with continuing population growth, are resulting in the generation of ever-increasing amounts of solid waste.

- Before promulgation of stringent land disposal restrictions and stringent air pollution control regulations, federal, state, and local governments tended to underestimate the importance of safe and effective waste management.

- Regulatory and technological attention has usually been devoted to other, more urgent environmental problems.

- Products are generally designed, manufactured, and packaged without life-cycle consideration.

- Individual consumers give little thought to life-cycle considerations and disposal in their purchasing decisions.

- Disposal facility owners have generally not considered environmental issues to be significant, except in terms of compliance with legal obligations.

\subsection{Municipal Solid Waste}

Municipal solid waste is the waste produced by the general public in normal day-to-day activities in residences and businesses. This portion of the waste stream is generally managed collectively, with the major portion of the waste being disposed in sanitary landfills.

Municipal solid wastes are defined and regulated as Subtitle D wastes under the Resource Conservation and Recovery Act (RCRA) in the U.S. Subtitle D wastes considered as MSW include household wastes, hazardous household wastes, and some commercial wastes. Many disposal sites handle non-hazardous industrial solid waste in the same manner as MSW.

MSW comprise only a small portion of the total solid waste generated annually in the U.S., compared to other waste categories such as ISW, industrial hazardous waste, and Superfund wastes. The majority of the information available on solid wastes, however, resulted from studies of MSW. This is because MSW has been studied in much greater detail than other categories of non-hazardous solid waste, and records are generally more available to the public. Almost without exception, however, MSW practices and their impacts can be extrapolated to the other solid waste categories. 


\subsubsection{Quantity and Composition}

Waste quantities and compositions differ from study to study, for two reasons: 1) waste generation is not uniform from place to place, or from one group of people to another, or from one period of time to another, and 2) because of the different methods of measurement and different waste classifications adopted for reporting data. However, it is clear that worldwide waste quantities are continuing to grow each year. While recycling and source reduction have begun to reduce waste quantities in some areas, their slow growth worldwide has resulted in minimal reductions of the total waste quantities (Meadows and Randers, p. 84).

According to EPA data for 1990, an estimated 196 million tons of MSW were generated in the U.S. in that year, a $19 \%$ increase since 1985. This is equivalent to each American producing 4.3 pounds of trash every day (i.e., 1,570 pounds/year) (Hammond 1993, p. 90). Another source, the annual survey conducted by BioCycle magazine, states that 291 million tons of MSW were generated in the U.S. in 1992, and 307 million tons in 1993; these figures include some commercial, residential and institutional wastes, industrial wastes, and sewage sludge that were not included in the EPA figures (Steuteville and Goldstein 1993; Steuteville 1994).

The U.S. generates twice as much solid waste per capita as most other industrialized nations, although Australia, New Zealand, France, and Canada generate more per capita (Hammond 1993). Available data indicate that per capita waste generation in the U.S. is increasing. The U.S. constitutes only about $4.5 \%$ of the world's population, yet generates about one-third of the world's solid waste (Miller, p. 519). Per capita solid waste generation of less-developed countries is typically less than one-half that of the U.S.

MSW is generated by all sectors of the economy, including households, commercial businesses, institutions, and low-volume industrial generators. MSW composition varies greatly from region to region and country to country.

Household MSW consists of items such as food wastes, paper, packaging, appliances, clothes, yard wastes, street sweepings, ashes, hazardous household waste, animal wastes, and other household wastes. Non-household items are also often found in MSW streams. For instance, DOE's Office of Industrial Technology estimates that 70 million tons per year of industrial wastes are accepted at municipal sanitary landfills (OIT 1992, p. 9). Earthquakes, hurricanes, and other natural disasters generate large waste quantities which ar4.4e often sent to landfills. Construction and demolition wastes and various types of commercial wastes may all be disposed of in the MSW stream.

Figure 2 shows the typical composition by weight of the U.S. MSW stream (EPA 1992, p. ES-4). Items in the other category include treated sewage sludge, rubber, textile and clothing, disposable diapers, hazardous household waste (HHW) and other miscellaneous items. It is not certain whether tires are included in this analysis, but another source states that tires are about $1 \%$ of the MSW stream. Less than $1 \%$ of the MSW stream is considered hazardous household waste, consisting largely of automotive products, household cleaners, paints/solvents, batteries, medicines, pesticides and other miscellaneous hazardous chemicals, products, or medicines (Characterization of Municipal Solid Waste Program in the U.S.: 1992 Update, ES-4). 


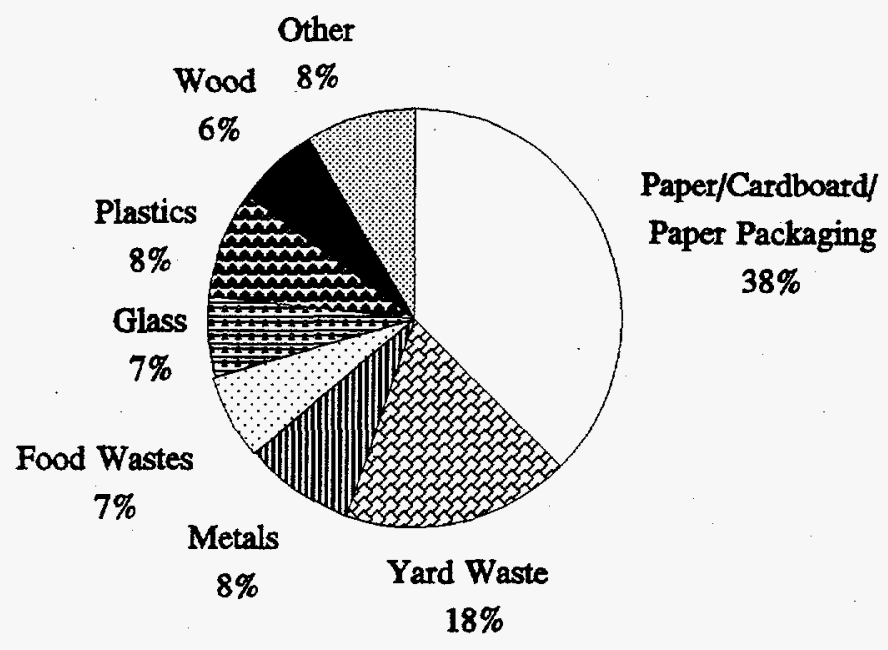

Figure 2. Typical Composition of U.S. MSW Stream

A further breakdown of waste quantities and compositions can be found in various EPA publications and in BioCycle magazine's annual "State of Garbage in America Survey."

\subsubsection{Disposal Options and Technologies}

Several disposal options are available for MSW streams:

Landfilling of municipal solid waste is the primary means of disposal in the U.S. for about twothirds of the U.S. solid waste stream (Steuteville 1994). Some institutional, commercial, and nonhazardous industrial solid waste is also disposed of in municipal solid waste landfills. The level of environmental protection at U.S. MSWLFs, otherwise known as Subtitle D MSWLFs or sanitary landfills, is fairly typical of many industrialized countries, while LDCs practice crude dumping in open landfills, streets, and waterways.

Municipal Waste Combustion (MWC) handles an estimated 10 to $16 \%$ of U.S. MSW annually at 169 waste combustion facilities in the U.S. Approximately 125 of these MWC facilities are waste-to-energy (WTE) plants which burn wastes to generate electricity (Integrated Waste Management, 11/24/93, pp. 1, 4). Many other industrialized countries, most notably, Japan, Germany and Sweden, use WTE and/or MWC to handle waste streams and generate electricity. Countries with high population density tend to incinerate a larger percentage of their wastes; Japan incinerates more than $70 \%$ of solid wastes. Industrializing countries and LDCs often practice open burning of some wastes. 
Recycling and Composting combined divert roughly $19 \%$ of total U.S. MSW from landfilling or other disposal options (Steuteville 1994) and current regulatory trends are likely to increase this percentage. Curbside collection and dropoff box programs in the U.S. have increased steadily over the past decade, along with an increasing number of sorting, baling, and distribution facilities for recyclable materials, called Material Recovery Facilities (MRF). Composting facilities for processing yard wastes and other organic wastes into useful soil amendments have also experienced considerable growth in the recent past.

An integral component of all MSW management methods just mentioned is waste handling, collection, and transport. Handling and transport methods, equipment and options are diverse, and include shipment by truck, rail, and water.

\subsubsection{Waste Management and Regulation in the U.S.}

The U.S. Environmental Protection Agency (EPA) is responsible for enforcing waste management regulations at the federal level. Many states and counties have varying levels of solid waste

regulations, often more stringent than federal regulations, but tailored to local and regional conditions.

Federal regulations under Subtitle D of RCRA govern solid waste management in landfills in the U.S. Subtitle D was revised in late 1993 resulting in much more stringent requirements for controls in landfilling. Subtitle D is now jointly promulgated under the Clean Water Act establishing adequate protection of groundwater. Revisions to the New Source Performance Standards under the Clean Air Act (CAA) are expected to be promulgated in the near future to require collection and removal of non-methane organic compounds (NMOC) in landfill gases. The Clean Air Act Amendments of 1990 require the EPA to establish limits on many common pollutants in waste combustion emissions. Recycling and composting legislation has been promulgated by many states and is being investigated or proposed by many more states.

The EPA promotes an integrated waste management hierarchy, by order of disposal methodology:

1) source reduction

2) recycling (including composting)

3) landfilling or combustion.

One of the most important management opportunities is source reduction, which seeks to prevent creation of waste or reduce toxicity of waste at every stage of a product's life, from raw material extraction through production, transport, purchase, packaging and end use. As an example, a 5\% overall source reduction in the U.S. would result in of a savings of 9.8 million tons of MSW per year, based on 196 million tons of MSW generated in 1990 (EPA 1992, p. ES-3).

The EPA waste management hierarchy is sometimes criticized for its lack of flexibility but emphasizes the importance of reducing wastes at generation, utilizing secondary waste streams, and minimizing dependence on landfilling and combustion as primary disposal methods.

Solid waste management activities are divided among a fragmented industry with about $30 \%$ of the revenue earned by publicly traded companies, $25 \%$ by private operators, and $45 \%$ by government-owned facilities. More than $50 \%$ of U.S. disposal business is dominated by two large 
companies (Miller 1992). With trends toward large, regional landfills and the cost of more stringent environmental controls, the shift in landfill ownership is expected to continue away from privately owned facilities to commercially owned and operated landfills.

\subsection{Industrial Solid Waste}

Although some ISW is very similar to MSW, ISW can often be distinguished from MSW because of waste source, quantities, compositions, and management practices. The majority of ISW is generated during industrial processes and is composed of byproducts from activities such as extractions and mining operations, industrial and electronic manufacturing, electric power generation and utilities, oil and gas industry, CDL, and agricultural and forestry operations. ISW is generally managed onsite, at the point of generation, or sent offsite to either ISW or MSW facilities.

\subsubsection{Quantity and Composition}

Industry produces much more solid waste than the municipal sector in the U.S. The most recent national data available from the EPA are from a 1986 Industrial Survey. The quantities presented in Table 1 (from EPA 1988, p. 36) include only solid industrial wastes, disposed in ISW landfills, land application units, or waste piles. The data exclude industrial liquid or sludge wastes disposed in ponds, lagoons, or surface impoundments. With industrial growth in the past decade, it is expected that the annual quantities generated in industry today are higher than those reported in the table.

Table 1. Results of 1986 EPA Survey on Industrial Solid Waste Sources

\begin{tabular}{|l|c|}
\hline \multicolumn{1}{|c|}{ Industrial Solid Waste Source } & $\begin{array}{c}\text { Waste Quantity } \\
\text { (million tons) }\end{array}$ \\
\hline Food and Kindred Products & 80.0 \\
\hline Electric Power Generation & 54.6 \\
\hline Inorganic Chemicals & 44.6 \\
\hline Stone, Clay, Glass, and Concrete & 16.8 \\
\hline Pulp and Paper & 16.3 \\
\hline Fertilizer and Agricultural Chemicals & 11.4 \\
\hline Primary Nonferrous Metals & 10.5 \\
\hline Primary Iron and Steel & 9.8 \\
\hline Plastics and Resins Manufacturing & 3.3 \\
\hline Organic Chemicals & 2.1 \\
\hline Other Industries & 12.8 \\
\hline Total & 263.3 \\
\hline
\end{tabular}


Other Subtitle D solid wastes not included in Table 1, which for the purposes of this report are deemed ISW, include CDL wastes at 31.5 million tons per year (EPA 1988, p. 11; Hammond 1993, p. 91 ).

\subsubsection{Disposal Options and Technologies}

Nonhazardous ISW is the majority of the solid waste stream in the U.S, yet receives less public, regulatory, and management attention than MSW. U.S. land disposal has been phased out for an ever-increasing list of industrial wastes legally defined as hazardous. The diversity in types of nonhazardous ISW is matched by a diversity in disposal methods. Approximately 70 million tons per year of ISW are accepted at U.S. MSWLFs. The remainder of the nonhazardous ISW is disposed of at ISW landfills or waste piles and land application units. About 13,000 ISW land disposal units were active in 1988.

Industrial landfills are onsite areas of land or an excavation in which wastes are placed for permanent disposal. Many industrial landfills are monofills, meaning they dispose of only one type or a few related types of wastes generated at a given facility or by a particular industry. The most common applications of monofills are for combustion ash disposal and CDL waste.

A waste pile is any non-containerized accumulation of solid non-flowing waste material that can function as a treatment or storage site. The most common examples of waste piles are large soil mounds, tailings piles from mining operations, and slag from smelting operations. Ash residuals from combustion of coal and other fuels, from cement kilns, and from combustion of municipal or industrial waste are disposed in waste piles also or in ISW landfills. Industrial solid waste landfills and waste piles are often located near or on the property of an industrial facility.

A land application unit (frequently called land treatment, land farming, or land spreading) is an area of land (not necessarily onsite) where wastes are applied on or incorporated into the soil. Land application can act as a beneficial soil amendment, as well as a means of waste treatment and disposal, depending on the type of waste involved.

Other methods of disposal are similar to MSW methods and include combustion (including WTE), recycling of industrial scrap and other office-type wastes, composting or fuel conversion of agricultural wastes, and waste exchanges.

\subsubsection{Waste Management and Regulation in the U.S.}

Although the federal government and most states have adopted stringent controls for hazardous waste programs and MSW management, nonhazardous industrial waste disposal has received less regulatory attention (Dernbach 1990). Thus, design, operating, and environmental controls for ISW are typically less stringent than for MSW.

Subtitle D, Part 257 of the RCRA, provides voluntary guidelines for state solid waste management of nonhazardous. ISW. The waste disposal criteria specify very generic and minimum requirements for protection of surface waters and groundwaters per the Clean Water Act and Safe 
Drinking Water Act (SDWA). U.S. states have industrial waste regulatory programs that have varying degrees of depth, sophistication, and protectiveness. In many states, regulation of ISW is bound together in varying ways with MSW.

Owners and operators of industrial facilities are responsible for management of onsite waste facilities which account for treatment, storage, and/or disposal of most nonhazardous industrial waste streams. Some industrial waste generators are taking extra precautions with industrial wastes and paying to dispose of them in permitted hazardous waste facilities, lest the wastes be classified as environmentally harmful or hazardous in the future, rendering them liable for Superfund cleanup. 


\subsection{Impacts and Trends of Municipal Solid Waste Practices}

This section describes pertinent impacts and trends in global solid waste practices.

\subsection{Pollution}

Multi-media pollution results directly and indirectly from various MSW practices. Direct pollution to the atmosphere occurs through airborne contaminants and gases from landfills, MWC facilities, compost piles, and transportation, compaction, and handling equipment. Direct pollution to groundwater and subsurface soils results from landfill leachate, and surface water pollution results from landfill runoff from waste repositories and composting piles. In addition, indirect pollution occurs through deposition of airborne and waterborne pollutants on surface waters, soils, and vegetation.

\subsubsection{Atmospheric Pollution}

The generation of landfill gases and emissions from incinerators are considered the most significant sources of air pollution associated with MSW disposal. Composting also results in some airborne releases. Vehicular emissions from collection and transportation and earth-moving and compaction equipment also contribute to air pollution.

\section{Landfilling}

As organic material in landfills degrade, gases are produced that can migrate to the surface and escape to the atmosphere. Despite fairly efficient gas collection systems, caps, and daily covers in modern U.S. municipal solid waste landfills (MSWLF), unexpected leaks and emissions continue to occur and are often difficult to detect. Although gas production decreases with time, landfill gases continue to be generated for several decades after disposal, as long as organic degradation of the wastes continues. In some cases, the presence of subsurface methane, a potentially explosive component of landfill gas, has hindered residential and commercial development in areas surrounding former landfill sites.

Although the composition of landfill gas varies greatly depending on the waste composition and burial conditions, almost all landfill gas is between 40 and $60 \%$ each of methane and carbon dioxide. Methane is estimated to be 30 times more potent than carbon dioxide in contributing to global warming. Methane is believed to be responsible for about $20 \%$ of the current increase in global warming (World Resources 1994-95, p. 364). A 1987 study by Bingemer et al. estimates that between 30 and 70 million tons of methane is produced annually from world landfills and waste dumps based on the amount of degradable organic carbon sources disposed (p. 2185). With published estimates of methane generated in landfills ranging from 6 to $36 \%$ of the global methane releases, and as much as $27 \%$ of U.S. methane emissions (World Resources 1994-95), it is clear that methane production in landfills can have a significant impact on global methane releases. 
A number of other gases including hydrocarbons, nitrogen oxides, ammonia, vinyl chloride, hydrogen sulfide, other non-methane organic compounds(NMOC), and metal vapors are also generally present in landfill gases. Although these trace gases constitute only 2 to $9 \%$ of the total landfill gas volume (Tchobanoglous, et al., p. 382), these gases can present significant risk to human health and the environment and can contribute to major environmental or health problems in proximate areas.

Many landfills collect and vent or flare (burn) landfill gas. Collected gas may be used as an energy source, but is more often flared. Flaring of methane converts the methane to carbon dioxide and water and removes many of the other pollutants from the gas prior to release to the atmosphere. Carbon dioxide is also a greenhouse gas but is about thirty times less potent than methane per molecule. The contribution of carbon dioxide to the environment by landfills is extremely small in comparison with other sources and should not be a major concern.

Problems exist with former MSWLFs that did not restrict hazardous or environmentally harmful wastes or require daily cover as now mandated in Subtitle D regulations. EPA data from MSWLFs listed on the NPL in 1988 showed air emission problems at $16 \%$ of the sites (EPA 1988, p. 22). Also, white goods formerly buried in older landfills may emit ozone-depleters such as chlorofluorocarbons (CFCs) in discarded air conditioners or refrigerators. Current regulations requiring complete removal of the CFCs from appliances prior to landfill disposal and the planned global phase-out of CFCs should limit further CFC pollution.

TRENDS: Modern landfills are getting larger, and thus are coming under stricter regulations. At the same time, landfill gas collection technology is getting better. Regulations are also focusing more attention on landfill gas releases. Therefore, releases of landfill gases have become more of a problem in LDCs than in the industrialized countries.

Further research and development in areas such as catalysis of landfill decomposition through recirculating collected leachate could potentially reduce landfill gas and decrease settlement time in closed landfills.

\section{Municipal Waste Combustion}

Although combustion of waste at WTE or incineration facilities decreases the waste volumes going to landfills by as much as $90 \%$, there are concerns with the emissions from these facilities. Due to long residence times in the atmosphere, some airborne pollutants from MWC travel hundreds of miles from the source before deposition on land, soil or waterways. Although the majority of airborne effluent is carbon dioxide and water, other emissions include oxides of nitrogen and sulfur, toxic metals or metal vapors, hydrogen chloride (an acidic gas), dioxins, furans and particulate matter. In particular, there has been considerable debate on dioxin and furan emissions. These complex and persistent chemicals are emitted when halogenated hydrocarbons, chlorinated compounds, and some plastic resins and their additives are burned. The health effects of exposure to these compounds are not well understood nor is their relative contribution to the environment by WTE and incineration plants. MWC facilities and paper mills are the only dioxin-producing sources currently regulated even though chemical companies, utilities, steel makers, the transportation sector, and several other industries emit dioxins to the atmosphere. MWC facility operators and owners argue that their contribution to background dioxin levels is very small (Solid Waste Report, 5/12/94, p. 153). 
Trace pollutants in emissions are often a result of non-combustible constituents in the waste, for instance, lead in newsprint ink or heavy metals in batteries that were not removed prior to combustion. Presorting of waste streams prior to combustion is practiced at an increasing number of MWC facilities and can prevent such toxic emissions. A recent Supreme Court ruling that incinerator ash is not exempt from hazardous waste status will most likely bolster this trend.

Air pollution control devices are required at MWC facilities, with performance standards specified under the Clean Air Act (CAA); however, complete removal of contaminants is not feasible. Although there are continuing improvements to air pollution control equipment, costs dictate limitations in the removal efficiencies for the various pollutants.

The majority of air pollutants emitted from WTE facilities are in quantities less than those from coal-fired power plants for an equivalent amount of energy generated (Zandi 1991, p. 169). A published study (1989-1991) shows that MWC in the U.S. contributes about $18 \%$ of all identified airborne mercury emissions while coal-fired power plants were responsible for nearly $36 \%$ (Hammond 1993, p. 74).

TRENDS: Controls and monitoring of airborne releases from MWC are getting more strict, and public pressure is increasing to ensure adequate removal and destruction of pollutants.

Waste segregation before combustion to reduce emissions is also increasing.

\section{Other Solid Waste Practices}

In most recycling processes, using recovered materials generates much less air pollution in the manufacture of a new product than if virgin materials were used. Some recycling processes do generate deleterious air pollutants such as bleaching chemicals to de-ink the recycled paper pulp and spent solvents containing volatile organic compounds (VOC) used to remove water-insoluble glues and impurities. Recycling also results in the added emissions from separate collection and transport of recyclables, which detracts somewhat from savings in air pollution from recycling.

Compost heaps can emit odors, airborne microbes and pathogens, and other bioaerosols purportedly responsible for local environmental problems. Technology is available to minimize odors with odor removal equipment and close monitoring and control of aeration and moisture content.

Tires are kept out of sanitary landfills due to certain characteristics such as "surfacing" and moisture retention. Although many new uses for spent tires have been and are being developed, many tires are still disposed in large piles around the country. Tire piles are often prolific breeding grounds for mosquitoes and create other possible disease hazards, due to standing water contained in the tires. Although infrequent, fires at tire piles can cause serious local and regional air pollution.

As MSW is collected and transported to a disposal or recycling facility, hauling vehicles emit gaseous pollutants. Vehicular emissions and dust particles from waste handling trucks and machinery are difficult to quantify because they are only one component of the transportation sector. Vehicular emissions include carbon dioxide, carbon monoxide, various organic pollutants, nitrogen oxides, aerosols, and sulfur dioxide. These pollutants contribute to global warming, local smog, and acid precipitation. Onsite compaction and earthmoving equipment at landfills stir dust into the air, which can be a problem in non-attainment regions for particulate matter. 
TRENDS: As waste volumes increase, many of these releases will also increase.

Composting is currently growing, transportation distances are increasing as landfills are sited farther from the waste sources, and recycling is increasing with its need for additional transportation of materials. All of these factors tend to lead to somewhat increasing releases. On the other hand, increasing recycling may reduce the need for virgin materials and their production, thus offsetting releases from those sources. In general, these releases are not of major importance when compared with all sources of similar releases in modern society.

\subsubsection{Land and Water Pollution}

Land and water pollution occur directly during disposal or combustion of MSW. Contamination also results as a side effect of the air pollutants mentioned above as airborne contaminants deposit on land, vegetation, and surface waters.

\section{Landfilling}

Leaching is the most direct pathway of land and water pollution. Leachate forms as wastes buried in landfills decompose or as rainfall penetrates landfill covers or capped landfills and percolates downward through the waste. Heavy metals such as lead, mercury, and cadmium in batteries, some plastic resins, and other items can leach to groundwater. However, because of land disposal restrictions of untreated hazardous or toxic wastes since 1980, and groundwater protection measures in 1993 Subtitle D regulations, leachate from current MSWLFs will pose little or no current environmental threat unless hazardous wastes illegally or mistakenly reach MSWLFs. Absolute screening and removal of hazardous household wastes is impossible, and such items can corrode landfill liners and result in leachate contaminating the soil or groundwater.

Serious leachate problems from untreated/uncleaned municipal landfills on the NPL Superfund list remain today. Over 200 chemical constituents could be found in MSW leachate resulting from landfill disposal practices before 1980. Data from the EPA on NPL landfill sites as of 1988 showed presence of halogenated organics, aromatics, and metals at most NPL sites. Releases of hazardous materials to groundwater were documented at nearly $75 \%$ of the sites and surface water releases at $43 \%$ of the sites.

Less-severely contaminated pre-1980 landfills not included on the NPL (of which there are an estimated 40,000 in the U.S. [Hammond 1993]) also pose potential pollution problems that are more serious than those from newer landfills in compliance with 1993 Subtitle D regulations.

Groundwaters and surface waters were contaminated with elevated levels of organics and metal contaminants at many sites as published in case studies by the EPA completed in 1988 . Groundwater quality was adversely affected at 146 landfill sites evaluated in this study, and surface water was adversely affected at 73 sites (EPA 1988). Leachate of hazardous constituents buried within these landfills is contaminating drinking water sources and local water supplies.

Runoff of surface waters is controlled in modern landfills to prevent release from the site. However, heavy rains during storms can still lead to significant quantities of runoff requiring capture and treatment. The operating criteria in current Subtitle D of RCRA requires runon control to minimize infiltration. Runoff from the active portion of a landfill must also be controlled and 
maintained and handled (Peters 1992, p. 10). Runoff of contaminated surface wastes from older landfills is only a problem in cases where wastes were placed in open dumps, or where the landfill cap has been damaged, exposing the waste to surface water.

TRENDS: Leachate collection and monitoring are improving as older landfills are phased out. In addition, segregation of problem wastes (e.g., batteries) is reducing potential releases. However, practices in LDCs continue to present significant potential for major leaching and release of materials from solid waste.

\section{Municipal Waste Combustion}

Airborne pollutants from incinerators and WTE facilities can deposit on surface waters. Acid precipitation resulting from acid gases and sulfur dioxide emissions can pollute waterways and heavy metals in airborne effluents can deposit on surface waters.

Although relatively inert, ashes from incineration and WTE are disposed in sanitary landfills or ash monofills which can contribute to leachate and runoff. Ash monofills generate up to an order of magnitude less leachate than MSWLFs (NREL 1992), mostly because of the removal of organics. Depending on the composition of the feed waste stream, ash often contains elevated levels of minerals, heavy metals and other products of incomplete combustion, and these contaminants can be leached.

TRENDS: A 1994 U.S. Supreme Court ruling requires that all incinerator ash must be tested for hazardous characteristics to determine if the waste will require disposal as a classified hazardous waste (Solid Waste Report, 5/5/94, p. 145). This ruling should prevent future hazardous leachate or runoff problems from ash disposal. Additional protection is occurring because many facility operators are segregating a large percentage of non-combustible items, many of which are recyclable, from the feed waste stream prior to combustion to avoid toxicity problems and to economically recover the materials.

\section{Other Solid Waste Practices}

Recycling most commodities substantially reduces land and water pollutants when compared with creating the same product from virgin materials. For example, aluminum products from recycled aluminum generates $97 \%$ less water pollution and paper recycling reduces water pollution by as much as $35 \%$ (Miller 1992, pp.398, 531).

During processing at compost facilities, runoff and leachate from the decomposing material can lower the quality of surface and groundwater near the site. Many states now require facilities to compost on concrete pads and install leachate control and monitoring systems. End-product compost applied as fertilizer or soil amendment can also provide a mechanism for metals and other contaminants to enter the food chain.

Disposal of solid wastes by merchant vessels, boaters, and beachgoers in oceans has recently received considerable attention. According to a video published by the National Oceanic and Atmospheric Administration in 1988, world merchant vessels daily dump 4.8 million metal cans, 450,000 plastic containers, and 300,000 glass bottles into the oceans. The video also states that 
recreational boaters dump 1.5 pounds of garbage/person/day. Such dumping off U.S. coastal waters is illegal and violators are subject to large fines when caught. Plastic wastes dumped from ships and left as litter on beaches threatens the lives of millions of marine animals each year because of ingestion, choking, strangulation, or when the plastic wraps around the mouth or beak.

TRENDS: As recycling increases, water pollution resulting from the extraction and processing of virgin materials should be reduced.

Composting is also increasing but, at the same time, regulatory controls are increasing. The net impact on waste pollution of composting trends is indeterminate.

Activities are under way to reduce ocean pollution from waste dumping. The London Dumping Convention was established in 1972 to reduce pollution of the sea by the dumping of waste. This document discusses allowable disposal practices, and resulted in widespread international agreement in 1988 to proceed towards the termination of ocean incineration of liquid noxious wastes by 1994 or earlier; agreement to not export wastes for dumping at sea to non-member states; and a decision in November 1990 to phase out industrial waste dumping at sea by 1995 . Measures are being continued to ensure that potential adverse impacts of any dumping are minimized, and that adequate monitoring is provided for early detection and mitigation of these impacts (Karau 1992).

\subsection{Human Health and Safety}

Many of the pollutants discussed above, generated from solid waste practices, can pose health threats to humans if exposure pathways, contaminant concentrations, and proximity to the source are supportive. Today's level of environmental control in the U.S. for MSW management practices is mostly driven by increasingly stringent regulations, and is less likely to pose health or safety risks to the general public or workers than past practices, or practices in LDCs. However, lingering contamination from past disposal practices may continue to present a hazard to human health and the environment for many years.

\subsubsection{Public Health and Safety in Industrialized Countries}

\section{Landfilling}

Potentially toxic decomposition products from putrescible organic wastes contaminate air, water, and land resources. If not properly managed, MSWLFs can result in nuisance conditions and provide mechanisms for disease transport. Current regulations require daily cover of six inches of dirt or coverage material to reduce these problems.

Contamination from former MSWLFs on the Superfund NPL list, and past landfills closed prior to requirements for leachate and explosive methane control, may pose significant threats to human health. Table 2 lists MSW leachate constituents deemed as some of the most serious threats to human health in an 1988 EPA report of former landfill sites given their observed concentrations in the leachate, their toxicity to humans, their regulatory limits under the Safe Drinking Water Act, their taste and odor thresholds, and their mobility and persistence in the subsurface environment. 
Table 2. Harmful Solid Waste Leachate Constituents

\begin{tabular}{l} 
Leachate Constituent \\
\hline Vinyl Chloride \\
Arsenic \\
$1,1,2,2,-$ Tetrachloroethane \\
Methylene Chloride \\
Antimony
\end{tabular}

Carbon Tetrachloride

Phenol

Risk
human health risk (cancer)
human health risk (cancer)
human health risk (cancer)
human health risk (cancer)
human health risk (systemic
poison)
human health risk (cancer)
resource damage (taste \& odor)

(Source: EPA 1988)

The health problems related to landfill gas emissions are fairly local problems. Several NMOCs commonly found in landfill gas are known or suspected carcinogens and other NMOCs contribute to smog formation, which can cause localized respiratory problems.

TRENDS: Landfills are becoming larger resulting in greater quantities of potentially harmful materials at a single location. This poses a greater threat to public health from any one landfill. However, regulatory controls on air emissions and leachate control will also be greater. Thus, the net impact of these changes is unclear.

\section{Municipal Waste Combustion}

Municipal waste combustion can pose health threats through direct air pollution, deposition of contaminants, and by residual ash disposal. It is important to note that MWC is only one of many contributors to airborne emissions, including dioxin and furan emissions. Although various studies have been conducted, the significance of dioxin as a risk from waste incineration remains unclear.

Volatile heavy metals can vaporize during combustion and be emitted directly in off-gases or can adsorb to particulate matter emitted from the stack. Mercury and cadmium are considered to be two of the more toxic of these metals.

The effects of long-term human exposure to trace elements and heavy metals resulting from MWC are not totally clear. However, it is unlikely that pollutants from MWC pose a major threat to humans (at least in the U.S.) because presorting and air pollution control devices generally result in extremely low releases.

Acid gases contributing to acid precipitation, sulfur dioxide contributing to smog, and other airborne pollutants from the MWC stack or from residual ash piles are potentially harmful to human 
health. Again, MWC is only one source of these pollutants, and is not believed to be a major source of these pollutants beyond the surrounding area.

TRENDS: Trends related to human health from MWC are similar to those listed above for pollution.

\section{Other Waste Disposal Practices}

If HHW are improperly disposed by homeowners (e.g., by "hiding" them in normal garbage), real threats to human health exist. As an example, used oil is a major concern because a significant volume produced by at-home oil changers is not showing up in collection efforts. It is likely these HHW are winding up in facilities not designed for hazardous waste disposal, thus increasing the chance of exposure to the public.

Airborne mold spores (such as Aspergillus fumigatus) and bioaerosols which can carry microorganisms are released during the composting process. If not properly managed, these can lead to human respiratory tract illnesses, infections, and other diseases. Most parasites and pesticides typically decompose due to the high temperatures of the compost and are rarely detected in the final product. However, if heavy metals are present, they will remain in the final product.

Many claims have been filed against compost facilities, stating that these facilities are responsible for local health problems. Research is under way to prove or disprove these claims, though no hard evidence exists of actual health impacts.

TRENDS: Controls and general public awareness on HHW are increasing. Segregation and collection (one-day events and HHW disposal facilities) of HHW are also increasing. These should result in reduced risks from these materials.

State governments are looking closer at the potential health impacts of composting. Several states participating in composting programs have regulations on compost quality. Permitted composting facilities must meet requirements that govern maturity, stabilization, pathogen reduction, thresholds for inert levels and contaminant levels, including heavy metals.

Restrictions are placed on the end-product compost if it fails to meet certain quality criteria.

Emissions may increase in the future as hauling distances increase and as smaller, proximate landfills are replaced by fewer, regional landfills. Expected increased use of rail to transport waste may provide some relief to the emission sources associated with waste transport.

\subsubsection{Worker Health and Safety in Industrialized Countries}

Most developed countries have strict operational requirements in waste management, resulting in much safer work conditions than in LDCs. Both private and public waste companies are responding to new state and federal regulations with stronger efforts to analyze the risk to waste workers and to provide protection from exposure to contaminants. Worker health and safety in industrialized countries is not a major impact. Worker health and safety issues are not perceived to be any greater than those in other industries. 


\subsubsection{Human Health and Safety in Less-Developed Countries}

\section{Land Disposal}

Open dumps are the most common solid waste disposal method worldwide, especially in LDCs. Due to a shortage of disposal options in many LDCs, residents dump solid waste on streets and into waterways, and dump untreated sewage in rivers and streams. Such crude practices often result in unintentionally dammed rivers, unsafe drinking water carrying intestinal and other bacteria, attraction of malaria-carrying mosquitoes, disease-carrying rats and other undesirable pests, and poor hygiene and sanitation. These conditions make some of a city's population susceptible to health risks. As an example, in India, untreated sewage and non-industrial solid wastes are rampant. "Waterborne diseases account for two-thirds of all illnesses." (Hammond 1992)

Most landfills in LDCs are unlined; allowing free migration of leachate to groundwater. Limited funding is available to maintain landfills and landfill equipment. This hinders compaction and moving certain wastes to proper locations within the landfill. In addition, waste is often burned without

pollution control devices to inhibit infestation by flies and vermin. Separate hazardous waste facilities are not usually available, and therefore dangerous constituents are free to leach into water supplies or escape to the atmosphere. Most LDC landfills have no fences or gates to ensure access control and scavengers comb the sites.

A few cases of sliding wastes, fires and explosions originating from gas generation of the wastes in open dumps have killed or injured people. In April 1993, an accident occurred in Turkey where a large mound of waste slid about 500 meters down into a valley covering eleven houses, killing 39 people (Kocagoy et al. 1993).

TRENDS: Increasing international attention on waste management practices (e.g., the UNCED resolution) is likely to reduce land disposal risks in the long run. In the short run, however, mounting pressures from increasing populations and continuing urbanization will strain available resources to cope with these issues.

\section{Open Waste Combustion}

Open burning of wastes is also commonly practiced in LDCs. This open burning presents the same types of hazards discussed above for MWC; however, because there are no controls on the airborne releases from open burning, the impacts are considerably more severe.

TRENDS: As indicated previously, increasing international attention on waste management practices is likely to eventually reduce the practice of open burning of wastes. In the near term, however, without added incentives, open burning will still remain a desirable method of reducing waste volumes in many areas of the world. 


\subsection{Economics}

Quantifying the economic value for the degradation of the environment resulting from solid waste is difficult. However, figures are available on actual costs to manage wastes. The EPA estimates the annual nonhazardous waste collection and disposal market at $\$ 31$ billion (Sanifill 1992, p. 8). In the past, landfills have always been a lower cost option when compared with other disposal facilities, but increasingly strict regulations are changing the price relationship between disposal options.

Costs are expected to continue to grow as ever-increasing quantities of waste are generated, waste regulations continue toward more stringent environmental controls, transportation needs increase, and opposition and (real or perceived) land scarcity increase for potential new disposal sites. These increasing costs are generally reflected in higher taxes and tipping fees. The willingness of the public to tolerate increased tax burdens for increased disposal costs remains unknown.

Economic incentives may have impacts on the waste generation levels. If products reflected more of the life-cycle costs, and subsidies were lessened, consumers would undoubtedly think more about their purchases and thus indirectly generate less solid waste. A few controversial incentives are in effect in some municipalities in the U.S., including unit pricing for garbage collection where generators are charged a fixed amount for the weight or volume of waste disposed. This program boasts an estimated $10 \%$ increase in waste diversion to recycling and composting, and a $10 \%$ cost savings over the unlimited-quantity pickup (EPA 1991). Deposit bills are another option, whereby the consumer pays a small deposit for beverage or other types of containers, and the deposit is refunded when the empty container is returned.

\section{Landfilling}

Construction, operation, maintenance, and closure costs for U.S. landfills complying with the current Subtitle D regulations are high. Operational costs are approaching $\$ 400,000$ per acre (Fisher 1993). Total disposal costs of landfilling in the U.S. for the year 1991, including collection, processing, and disposal, ranged from $\$ 59-\$ 194 /$ ton.

In 1992, the U.S. national average for landfill tipping fees was $\$ 29$. The lowest fees are in the midwest at around $\$ 14$ per ton and the highest fees are reported in the mid-Atlantic states with an average of $\$ 53$ per ton (Steuteville and Goldstein 1993, p. 48). The wide range in tipping fees reflects high-density populations and scarcity of landfill space in the eastern part of the U.S.

The costs of closing landfills are estimated in the range of $\$ 250,000$ to $\$ 350,000$ per acre (Fisher 1993). Operators must ensure site compliance for 30 years after closure.

TRENDS: Improved landfills, as required by new regulations, cost more money. U.S. landfill tipping fees appear to be on an upward trend. Total disposal costs of $\$ 128-\$ 219$ per ton are projected by 1996 (Hammond 1992, p. 50).

\section{Municipal Waste Combustion}

Since 1985, about 64 new incinerator projects have been blocked, delayed, or cancelled due to high costs or citizen opposition (Miller 1992, p. 525). A plant with a 1,000-ton-per-day capacity 
costs about $\$ 130$ million to build (Appel, Wall Street Journal, 5/23/94). Roughly one-third of this cost now goes toward air pollution control.

Tipping fees for waste brought to MWC facilities reflect the costs of collection, transportation, combustion, and ash disposal and any revenue from sale of electricity generated in WTE plants. In 1993, 20 states responding to The State of Garbage in America Survey reported tipping fees in a range of $\$ 22$ to $\$ 80$ per ton, with an average of $\$ 54 /$ ton (Steuteville 1994).

TRENDS: The EPA projects increases in tipping fees for incoming waste due to current regulations on air pollution, and a May 1994 ruling by the U.S. Supreme Court that MWC ash be disposed in compliance with hazardous waste regulations. The city of Chicago expected an increase in ash disposal costs from $\$ 23$ per ton if classified as nonhazardous to $\$ 210$ per ton if the ash is classified as hazardous (Hammond 1993, p. 100).

\section{Other Disposal Technologies}

Increasingly, local governments are seizing opportunities to avoid disposal costs by recycling and composting. Recycling programs are initially costly and cumbersome to communities because new trucks, sorting equipment, transfer stations and/or Materials Recovery Facilities (MRFs), and increased labor are required. Quality composting facilities and permitting of composting facilities are quite expensive.

Collection and transport is more expensive for recycling than landfilling, because compaction of commingled recyclables would inhibit sorting and, in those places where materials are sorted before collection, it is harder to get a full truckload before reaching capacity for one or two of the material categories. A study by Waste Management estimates a cost of $\$ 175$ per ton to pick up and sort recyclables, while the value of the final product is only $\$ 40$ per ton (excluding costs saved by not landfilling the recyclables.) Market prices for the final products from a recycling facility change frequently and vary greatly depending on demand for recycled materials and products made from them.

TRENDS: Longer transportation distances, coupled with separation of recyclable materials, are resulting in increasing costs. Regulatory drivers mandating an increase in the content of recycled material in various products should increase both the markets and the value of recyclables.

\subsection{Energy}

Substantial energy is embodied in solid wastes. The energy content for residential MSW is estimated at 1,700 to 2,600 kilojoules per kilogram (or 4,000 to 6,000 Btu per pound). Much of this energy is not utilized, but roughly $21 \%$ (OIT 1992, p. 1) of MSW is used productively to generate electricity at WTE plants or to produce new products after recycling. In addition, some energy is recovered from methane recovery at about 250 landfills worldwide (Bogner 1993, p. 370).

If current unproductive wastes were used to generate energy, and thus reduce energy consumption from fossil fuels, the wastes could produce, or conserve through recycling, close to three quads of 
energy per year (OIT 1992, pp. 1, 16). According to a study by the National Renewable Engineering Laboratory (NREL), combustion options produce the greatest energy savings and the most exportable energy, followed by landfill gas recovery and recycling (NREL 1992, p. 15).

WTE plants in the U.S. provide the equivalent energy of 31 million barrels of oil per year (Hamilton 1993), less than one-twentieth of 1\% of annual U.S. energy consumption (Annual Report to Congress 1992). MSW combustion has the potential to supplement fossil fuels on a far larger scale, but is not currently practiced to a significant extent. Japan, Germany, Sweden, and a few other countries also practice WTE combustion to supplement energy sources.

The energy required to manufacture most products from many of the recycled material sources is substantially less than if the same product were made from virgin material, as shown in Table 3 .

Collection and transportation of MSW requires substantial energy consumption. Because recyclables are generally not compacted in collection vehicles, lesser quantities can be hauled in one vehicle and more trips are necessary. However, these increased transportation energy requirements are far smaller than the energy savings realized from recycling.

TRENDS: There is increasing interest in WTE plants, recycling, and landfill gas recovery, all of which have the potential to contribute overall energy savings. However, WTE plants face political opposition and the overall economics of many recycling programs are being questioned, thus clouding the future for these options.

As the U.S. moves toward regional landfills, small collection trucks will have to haul waste longer distances, unless the waste is transferred to more efficient larger trucks or railcars. Transfer stations for waste transfer between collection trucks and long-haul vehicles are increasingly being built throughout the U.S. Rail access to disposal facilities is also available now in many locations.

Table 3. Energy Saved by Manufacturing from Recycled Products (MBtu/ton)

\begin{tabular}{lcccc}
\multicolumn{1}{c}{ Item } & $\begin{array}{c}\text { Energy for Virgin } \\
\text { Manufacture }\end{array}$ & & $\begin{array}{c}\text { Energy for Recycle } \\
\text { Manufacture }\end{array}$ & $\begin{array}{c}\text { Energy Saved } \\
\text { if Recycled }\end{array}$ \\
Newsprint & 27 & 22 & 5 \\
Corrugated & 17 & 17 & 0 \\
Tissue Paper & 12 & 14 & -2 \\
Aluminum & 100 & 5 & 95 \\
Steel & 48 & 23 & 25 \\
Glass & 10 & 7 & 3
\end{tabular}

(Source: OIT 1992, p. 12). 


\subsection{Land Use}

Landfill burial accounts for $71 \%$ by weight of the MSW in the U.S. The large amount of land required for landfilling leads to permanent loss of native ecosystems. After closure, landfill sites are revegetated and some are reutilized. Use of the land is limited to recreational or other restricted uses, and in some cases public access may be restricted due to continued generation and accumulation of subsurface methane or ongoing settlement of the land.

Locating land space for new disposal facilities in urban areas is a problem, sometimes due to public opposition, but also, in high-density metropolitan areas such as the mid-Atlantic east coast U.S. states, little suitable land is available at reasonable cost. In addition, many existing landfills have closed because of regulations, or are closing as they reach capacity. The closure of landfills in highly populated areas is creating disposal capacity shortages and waste flow control controversies.

Regulations govern much of the siting process for waste facilities in the U.S.; for instance, landfills are restricted to geologically suited areas, and various environmental and/or zoning permits are required for MWC, compost facilities, and landfills. Regulations also provide for public involvement in the siting process.

Landfill mining involves the removal and consolidation of landfill material. Related objectives for landfill mining, with respect to land use, are to reduce the area of a landfill prior to closure, to extend the life of an existing landfill, and to remediate contaminated sites or upgrade disposal sites to avoid leachate problems (Fisher 1993). Another benefit is an increased potential for material recovery from old landfills.

TRENDS: Fewer, larger landfills will be operating in the future, farther from major urban areas. Also, regulatory and social trends will exert pressure to achieve more ecological landuse planning.

Landfill mining has so far been conducted mainly as demonstration or pilot projects under tight regulatory control. Interest in landfill mining is likely to increase, however, as current landfills reach capacity and the costs of starting new landfills are compared with the costs of reclaiming operating landfills.

\subsection{Resource Conservation}

Air quality, water quality, land, and ecosystems have intrinsic value and are important to preserve for future generations. To manufacture new products from raw materials, mining, extraction, exploration, oil drilling, irrigation, and other environmentally destructive, waste-producing practices are required. In addition, land areas are lost and natural landscapes destroyed to construct landfills and other waste facilities required to handle wastes from throw-away societies. The quality of our natural resources are degraded by the subsequent contamination from waste facilities and by littering and illegal or unethical dumping.

As recovery of potentially useful materials from waste increases, the need for raw materials and energy and water is reduced. Solid waste in itself can be considered a resource because much of the 
material disposed in landfills has a high embodied energy and nutrient value, which at the very least could act as supplemental fuels to displace non-renewable fossil fuels, not to mention the reusable or recyclable materials included.

With respect to recycling, paper and aluminum are the commodities most successfully recycled by the public, at approximate rates of $33 \%$ and $63 \%$, respectively (Weyerhaeuser 1992; Tchobanoglous 1993). Tin, glass, scrap metals, aerosol cans, plastics and plastic films, polystyrene, and tires (for retreading) are commonly recycled, and fluids such as anti-freeze and vehicle oils can be recovered and refined. Composting of yard wastes and some food wastes diverts material from landfills and provides beneficial soil amendments.

Often, recycling requires less raw materials than producing products from virgin materials. As an example, to generate one pound of aluminum product from virgin raw materials, four pounds of bauxite ore, directly extracted from the earth, is needed (Tchobanoglous 1993, pp. 720-721), whereas one pound of recycled aluminum generates one pound of the same weight and quality of product. With about $95 \%$ lower energy consumption to produce recycled aluminum products compared with virgin aluminum, substantially less fossil fuels are required for production, which in turn lessens degradation of the earth from extracting fossil fuels.

Spent tires are another example of secondary resources that could reduce the amount of virgin materials currently consumed. Locked into the chemistry of each passenger tire is more than 1.5 gallons of recoverable petroleum (McPhee 6/93). As many as three billion spent tires are strewn across the country in landfills and tire piles, roughly equivalent to 178 million barrels of oil. Although the separation process is intensive, most of the constituents in tires (carbon black, oil, gas, steel) can be sold to rubber, plastics, chemical or printing industries, and/or utilities. Cement kilns are also using a portion of spent tires as supplemental fuel, with no significant difference in emissions from standard fuel sources.

Despite the popularity, growth, and benefits of recycling, problems exist. The primary problems are insufficient markets and stockpiling of materials such as green glass, high implementation and transportation costs, contamination present in the materials, and liability issues.

TRENDS: The list of recyclable commodities grows as technologies and markets are developing. Auto companies are producing cars that are $20 \%$ recycled content and up to 80 or $90 \%$ recyclable at the end of the life (Tri-City Herald, 5/21/94). Many U.S. municipalities are implementing new recycling and composting programs. Recycling and composting will likely continue to grow, diverting a higher percentage of the MSW from landfilling. Increased recycling will reduce raw material needs and consumption of natural resources.

\subsection{Source Reduction}

Source reduction seeks to change the unsustainable patterns of consumption and production typical of affluent countries. The goal is to reduce both the quantities and toxic constituents in solid waste streams at every stage of a product's life-cycle, from raw material extraction through production, 
transport, purchase, packaging, and end use. This requires attention by designers at the beginning of the design and manufacturing of both products and packaging. Attention at the consumer level is also important because selective purchasing habits can affect final waste streams.

Few legal requirements for source reduction exist in the U.S., although this is the topmost rung of the EPA solid waste management hierarchy. Germany, however, does have legal mandates for planned source reduction of 8 million tons of packaging waste each year. The program requires manufacturers to cover the costs of recycling or reusing packaging. An alternative concept, in which Advance Disposal Fees would be assessed on any packaging containers not made from a minimum of $50 \%$ recycled content material, has also been proposed to stimulate source reduction.

Through life-cycle assessment methodologies, products are being redesigned to minimize inputs, and less-toxic materials are being substituted to decrease risks associated with output wastes. For example, mercury will be legally phased out of household batteries by 1996 . Examples of quantity reduction include the elimination of cardboard for compact disk packaging. Encouraging grocery shoppers to bring their own bags, and buying products in bulk or in concentrate can help in reducing unnecessary packaging waste.

TRENDS: Source reduction is increasingly impacting the amount and characteristics of waste produced because of higher levels of public education and application of life-cycle assessments on products, processes, and packaging. This interest in source reduction is also spreading throughout the international community. 


\subsection{Impacts and Trends of Industrial Solid Waste Practices}

This section describes the known impacts and trends from non-hazardous ISW, excluding liquid wastes or processing sludges disposed or treated in surface impoundments or discharged into waterways or underground injection wells. The discussion is mostly specific to U.S. practices. because little information was found on global ISW management practices. Because a substantial amount of ISW is collectively managed in the same manner as MSW, only those impacts and trends associated with ISW managed in other manners than MSW sanitary landfilling, waste combustion, composting, or recycling are addressed in this section.

Available data on ISW are limited. One reason is that past data collection and reporting systems were often minimal, sufficient only to meet regulatory requirements. Another is that much of the data are privately held, and not generally released publicly. The data presented in Sections 5.1 and 5.2 are taken mostly from a 1988 EPA Report to Congress on the Solid Waste Disposal in the United States, from a followup publication by the Office of Technology Assessment in 1992, and from various publications from the state of Pennsylvania on ISW management and regulation in that state.

\subsection{Pollution}

Inadequate management of industrial waste presents a range of environmental risks similar to those presented from MSW. However, because of the quantities of waste and concentrations of pollutants within the waste, these risks are of potentially far greater consequence than those from MSW.

\subsubsection{Atmospheric Pollution}

Direct pollution to the atmosphere occurs through airborne contaminants and gases from waste repositories, waste combustion, and transportation and handling equipment.

Data from 1988, from 63 ISW landfills that actively monitored subsurface methane, indicated violations of state standards at eight sites (EPA 1988). Data from the few ISW landfills that monitored air emissions prior to the 1988 EPA study showed that 18 of 80 landfills, or $22.5 \%$, had air pollution in violation of state standards. This is the most recent data found and indicates that ISW landfill emissions are occurring in violation of standards established to protect against environmental or health risks.

The most common waste piles are mining tailings and waste rock piles and slag from smelting operations. Residual combustion ash may be stored in waste piles also. Overcover of waste piles is generally not required, allowing susceptibility to erosion, releases of airborne contaminants, and possible toxic substance emission. Mining tailings and waste rock piles may release airborne heavy metals, asbestos from asbestos waste rock, and naturally occurring uranium. 
Some ISWs are reutilized as fuel at the industrial plant itself, or are incinerated to reduce waste volumes or recover useful energy. The pollution impacts from burning ISW are generally similar to those from burning MSW, as discussed previously in Section 4.

TRENDS: Insufficient information was identified to accurately determine trends in this area.

\subsubsection{Land and Water Pollution}

Pollution to water sources can result from leachate and runoff from onsite industrial waste accumulations. Direct pollution of soil and vegetation results from leachate and from deposition of airborne pollutants.

Leachate is the primary pollution concern of ISW land disposal practices. The most important difference between industrial land disposal sites and MSWLFs is the number of liners required (Dernbach 1990, p. 6). For MSWLFs, a double liner system is considered a necessity, but state regulations often do not specify installation of liners for ISW landfills or leach pads for waste piles. EPA national data for ISW landfills showed that only $1.3 \%$ of 3,511 ISW landfills had synthetic liners, $11.2 \%$ had natural liners, and 3.2\% had leachate collection systems. No data were available for the number of leak detection systems at ISW landfills (EPA 1988).

Manufacturing wastes are so diverse that it is difficult to develop a comprehensive survey of the different types of waste, or to pinpoint specific types of pollution. Mining tailings and waste rock piles contain sulfides that can generate acid and metals that may leach to surface or groundwater. Cyanide used in treatment processes may be present in the solid waste residue as well. The majority of oil and gas industrial wastes are liquid wastes, with a small portion of the solids disposed in landfills or land application units. Coal combustion residuals may contain and leach oxides of silicon, aluminum, iron, calcium, magnesium, sodium, potassium or titanium, chloride and phosphorous ions, and/or low levels of cadmium, chromium, and arsenic.

Land application units, where wastes are directly applied to the land surface, can leach constituents to groundwater supplies and, if not properly managed, can also result in runoff into surface waters. The 1988 EPA study showed that of 5,605 land application units, $68.5 \%$ had runon and runoff controls and $72.9 \%$ had waste application rate limits (EPA 1988). Current regulations place controls on leachate of cadmium and PCBs in the ground at land application units. For land application of sewage sludge, disease vectors must be minimized, and pathogen destruction or removal must be ensured prior to application. It is unknown whether regulatory controls are sufficient to prevent detrimental environmental impacts from other contaminants that may be present in the applied wastes.

Ineffective past management at ISW disposal sites, including pre-1980 legal disposal of hazardous wastes in ISW land disposal units, may pose serious threats to human health and the environment. An example is a Superfund site in Carbon County, Pennsylvania, where a 2.5-mile-long waste pile of smelting slag containing zinc, cadmium, and other heavy metals has contaminated surface water and groundwater and has affected, probably irreversibly, the surrounding land. Although some sites are already designated as Superfund cleanup sites, many other ISW disposal sites have not yet been investigated for inclusion in the Superfund program. 
TRENDS: The awareness and support of waste generators in preventing pollution is increasing. A precaution being taken by many ISW generators to avoid potential future Superfund liability, is to pay the higher costs of disposing questionable nonhazardous ISW at permitted hazardous waste facilities. The ever-increasing list of legally defined hazardous and toxic wastes and the many ISWs that are very questionably close to being hazardous are driving this precautionary disposal (Solid Waste Report, 7/94, p. 223).

Some U.S. states are developing or revising ISW management implementation plans to surpass the minimal protection specifications in Part 257 of RCRA. These two provisions may lessen the severity of environmental contamination when compared to previous ISW handling practices.

More broadly, worldwide concern about ISW and its impacts is increasing, and so efforts at mitigating these impacts are increasing (UNCED 1992, Agenda 21).

\subsection{Human Health and Safety}

\subsubsection{Public Health and Safety in Industrialized Countries}

The 1988 EPA study concluded that risk to the general public from ISW practices is likely to be limited despite some offsite migration of leachate. The reasons are that most ISW management sites are not located in highly populated areas, and groundwater in that vicinity is typically not a drinking water supply. Also, unlined surface impoundments for storage and evaporation of liquid wastes (as opposed to solid waste) are a more likely contributor to leachate than the ISW landfills, waste piles and land application units. These generalizations can downplay the actual risk scenario for residents who live nearby and for those whose drinking water supplies are downgradient of the disposal facilities. In addition, the cumulative impacts of a number of such local situations can lead to considerable, widespread threats to public health and safety.

Due to the large volume of ISW waste, the broad range of potentially toxic constituents and the diversity of Subtitle D ISW regulations, land disposal units may present potential threats to human health (EPA 1988). Due to inadequate data, the 1988 EPA report provides inconclusive results regarding potential health risks from ISW land disposal sites.

Many of the potential health threats from multi-media pollution from disposal of ISW were from constituents also common to MSW. Not previously discussed are risks from friable asbestos, generally a local concern, and polychlorinated biphenyls (PCB), which may have been improperly disposed in the past in ISW land disposal units.

Currently, PCB-containing wastes previously disposed in ISW land disposal units threaten groundwater quality at many locations. PCBs are not readily biodegradable and bioaccumulate in the food chain. Laboratory data show that PCBs cause cancer in animals, adverse reproductive and developmental effects in animals from repeated exposure, and can cause liver damage and digestive problems in humans. 
TRENDS: There is considerable awareness of, and interest in, the potential public health impacts from ISW. As the use of hazardous materials comes under more strict control, this will help prevent increasing public health risks. However, the cumulative risks from a number of independent ISW sites can still be significant, and this type of cumulative effect is not always recognized and given serious consideration.

\subsubsection{Worker Health and Safety in Industrialized Countries}

Worker health and safety issues relating to ISW in industrialized countries are minimal, as discussed previously in Section 4.2.2 for MSW.

\subsubsection{Human Health and Safety in Less-Developed Countries}

The drive for industrial development, coupled with lagging concerns about pollution prevention and control, has resulted in serious pollution in a number of industrializing countries. Most human health impacts from ISW occur in industrializing countries.

As many as 5.2 million people, including 4 million children under five years of age, die each year from waste-related diseases. Part of this figure is due to nonexistent or poor sanitation, and due to contamination of waters from untreated industrial wastewater releases, but solid wastes definitely contribute to this problem.

TRENDS: There is increasing awareness and pressure to reduce impacts to humans from waste practices. The UNCED Agenda 21 provides goals and objectives for the United Nations and governmental bodies to improve conditions and lessen health impacts (UNCED 1992, Agenda 21).

\subsection{Economics}

The cost of disposing of nonhazardous ISW in municipal landfills and MWCs is essentially identical to that for disposing of MSW at these facilities. Actual costs for management of nonhazardous, onsite industrial waste piles, landfills, and land application units are not readily available, but costs are expected to rise as increasing regulatory attention is expected for ISW land disposal sites. Although the costs for ISW management are not clear, the total costs for management of ISW in the U.S. certainly exceed those for MSW management, simply because of the vastly greater volumes of ISW.

Much of the ISW disposed of in permitted hazardous waste landfills is considered legally nonhazardous and generators are paying the substantially higher price to dispose of the wastes to prevent future Superfund liability for these wastes if they were disposed in sanitary landfills (Solid Waste Report, 7/94, p. 223).

Recycling and reuse of most industrial scrap has a potential to provide substantial savings for companies in the purchase of raw materials, energy savings, disposal avoidance, and other areas. Inhouse recycling and/or purifying of chemicals is now in practice for many industries and saves on disposal costs and costs to purchase new chemicals. Chemical solvent recovery is a prime example. 
TRENDS: As the number of wastes legally defined as hazardous, or otherwise requiring specific treatment or disposal, increases, the costs for managing these wastes increases substantially. Stricter MSW regulations caused a sharp rise in MSW disposal costs; a similar cost increase is expected as state and/or federal regulations require more frequent and improved monitoring, data collection, and better disposal practices for ISW.

\subsection{Energy}

As with MSW, much embodied energy exists in ISW, some of which is recoverable. For instance, there are enough cement plants in the U.S. to burn three billion tires per year as supplemental fuel. (Use of tires for energy production was discussed previously in Section 4.)

Recycling of many products saves energy for industrial manufacturers. Recycling steel cuts energy consumption in half compared to steel production from virgin sources. In the paper industry, most of the energy used to make virgin paper comes from wood waste and black liquor, a by-product of the pulping process. Recycling mills that process only used paper must rely on fossil fuels for an energy supply. Published estimates of energy savings from used paper as a feedstock vary from zero to 10 million Btu per ton of paper product. Estimates vary according to the grade of paper recycled and the grade of paper produced (NREL 1992, p. 14). Table 3, presented previously, shows energy savings that can be achieved through recycling of various types of standard materials.

TRENDS: Increasing competition and increasing costs of energy and raw materials will continue to motivate industry to find more opportunities to reuse or recover energy from waste materials.

\subsection{Land Use}

The majority of ISW. land disposal sites are located within industrial facility property boundaries, in industrial districts of a community. Residential areas are or were usually built far enough away from industrial areas, more to avoid pollution from air emissions than from solid waste disposal. Therefore, residential property values are usually not directly affected by onsite waste disposal.

Landfills and waste piles, although on the site of the facility, can cover large tracts of land. Depending on the contents of a waste pile, and the level of control, runoff from waste piles can damage large areas of adjacent land, possibly outside the facility boundaries.

Land application units can detract from land value if harmful waste constituents contaminate soil, leach to drinking water supplies, or cause foul odors. On the other hand, land application of some industrial wastes can provide beneficial nutrients or prevent soil erosion, thus enhancing land value. 
TRENDS: Insufficient information was identified to accurately determine trends in this area.

\subsection{Resource Conservation}

Recycling is alive in the industrial sector, primarily because industry reaps economic benefit from recycling, but also because of public pressure to increase recycling. Scrap metals from metal refineries, fly ash, and paper products are some of the largest recycled commodities.

Metals scrapyards have gone through a role shift from collector to that of supplier, business developer, and regulatory partner. Waste combustion plants are annually recovering 540,000 tons of ferrous metals from waste streams prior to combustion (Hamilton 1993. p. 4). Metal smelting companies are recovering significant amounts of precious metals from metal-bearing wastes.

Fly ash and other residuals from coal combustion plants are currently reused at a rate of about $25 \%$ of the total quantity of solid waste generated (Blackstock and Tyson 1994). These products can be reused in blasting grit, roofing granules, cement, concrete, concrete block and pipe, lightweight aggregate manufacture, and in road base and subbase. Waste rock from mining operations is often reused as backfill at mining excavation sites.

In-house recycling and/or purifying of chemicals is now in common practice for many industries and saves on disposal costs and costs to purchase new chemicals. Prime examples are rerefining of chemical solvents and anti-freeze.

Composting is applicable primarily only to ISW streams from agriculture and food processing. No data were found on the amount of agricultural and food processing wastes that are reused or composted.

If byproducts and secondary wastes, and all scrap from industrial processes were recycled or reused, the destruction of natural resources for extraction of raw materials could be lessened. However, the timber, mining, and energy companies have historically received large tax write-offs to find and extract more natural resources of wood, oil, coal, and other natural resources. Instead of rewarding those who attempt to use resources more efficiently, such subsidies encourage further extraction of natural resources, which, in turn, generates waste.

TRENDS: Restrictions on consumption of some natural resources (e.g., logging and mining restrictions) on public lands are making virgin materials less available and more costly, increasing the incentive for recycling and use of specific secondary materials. On the other hand, government subsidies promote the use of some materials, resulting in disincentives for recycling of some materials.

Several waste exchange services have evolved in the U.S. They act as industrial matchmakers, allowing companies to sell and trade surplus materials and by-products. Increased participation by industry in programs such as this will conserve resources and reduce reliance on land disposal. 


\subsection{Source Reduction}

Federal laws encourage waste minimization for hazardous waste generators, but provide relatively little direct incentive for ISW generators to reduce volumes. Some states have established regulations for a source reduction strategy for ISW generators. The state of Pennsylvania has established regulations for a source reduction strategy for each generator of more than one metric ton of ISW per month (Dernbach 1990).

The American Institute of Architects and others in the building industry are actively promoting construction of buildings, factories, and residences using recycled-content products, toxin-free interior decor materials, and installing convenient recycling and waste collection systems. Buildings are equipped with resource-minimizing appliances, such as double-sided printers and copiers, and CFCfree refrigerators.

TRENDS: Environmental auditing of manufacturing and industrial plants is growing in popularity. Comprehensive inventory tracking of material inputs and outputs can help companies evaluate the environmental implications of their production processes, aiding in source reduction. 


\subsection{References and Bibliography}

\section{Books}

Ayres, E., L. Brown, and H. Kane. 1993. Vital Signs 1993, The Trends That Are Shaping Our Future. Worldwatch Institute, New York.

Brown, L. 1993. State of the World 1993. Worldwatch Institute, New York.

Diaz, L. F., G. M. Savage, L. L. Eggerth, C. G. Golueke. 1993. Composting and Recycling Municipal Solid Waste. Lewis Publishers, Florida.

Gore, A. 1992. Earth in the Balance. Penguin Books USA Inc., New York.

Hammond, A. ed. 1993. The 1994 Information Please Environmental Almanac. Compiled by The World Resources Institute, pp. 90-104, 319-327.

Hammond, A. ed. 1992. The 1993 Information Please Environmental Almanac. Compiled by The World Resources Institute, pp. 49-60, 460.

Meadows, D. H., D. L. Meadows, and J. Randers. 1992. Beyond the Limits. Chelsea Green Publishing Co., Vermont.

Miller, G. T. 1992. Living in the Environment. Seventh Edition. Wadsworth, Inc., California.

O'Reilly, J. T. 1991. State Local Government Solid Waste Management. Clark Boardman Callaghan, New York.

Tchobanaglous, G., H. Theisen, S. Vigil. 1993. Integrated Solid Waste Management. McGrawHill, Inc. New York, pp. 382, 640, 720-723.

World Resources, A Guide to the Global Environment. 1994-95. World Resources Institute. New York, pp. 94, 214, 217-219, 364, 365, 368, 369.

\section{Journal Articles and Technical Papers or Publications}

Ashton, W. B., J. R. Friedman, R. D. Rapopoit. June 1993. "A Review of the Global Emissions, Transport, and Effects of Heavy Metals in the Environment." PNL-SA-22394, Pacific Northwest Laboratory, Richland, Washington.

Bingemer, H. G. and P. J. Crutzen. 1987. "The Production of Methane From Solid Wastes." Journal of Geophysical Research 92, pp. 2181-2187. 
Bogner, J. and K. Spokas. 1993. "Landfill CH4: Rates, Fates, and Role in Global Carbon Cycle." Chemosphere. 26(1-4):369-386.

Carpi, A., L. H. Weinstein, and D. W. Ditz. 1994. "Bioaccumulation of Mercury by Sphagnum Moss Near a Municipal Solid Waste Incinerator." Air \& Waste.

Clean Washington Center. June 1993. "Used Oil to Diesel, An Alternative Technology." Report Number B21. Seattle, Washington.

Consumer Reports. February 1994. "RECYCLING, Is It Worth the Effort?" 59(2):92-98.

Consumer Reports. February 1994. "Out of Sight, Out of Mind? Where Household Goods Go?" 59(2):99-100.

Consumer Reports. February 1994. "Hazardous Waste at Home." 59(2):101.

Consumer Reports. February 1994. "Composting, Nature's Recycling Program." 59(2):112-113.

Dernbach, J. C. July 1990. "Industrial Waste: Saving the Worst for Last?" Environmental Law Reporter, pp. 10283-10294.

Freeman, D. 1994. "Waste-to-Energy (WTE) Fights Fires of Opposition." World Wastes, Jan:37, No. 1, pp. 24-28.

Hamilton, K. November 24, 1993. "Waste-to-Energy Plants Will Handle $20 \%$ of U.S. Trash by Turn of Century." Integrated Waste Management, McGraw-Hill, Inc. New York, pp. 1, 4, 5.

Holter, G. M. and D. C. Stapp. 1993. Solid Waste Initiative Macro Material Flow Modeling Conceptual Description and Requirements. PNL-8470, Pacific Northwest Laboratory, Richland, Washington.

McPhee, J. June 28, 1993. "Duty of Care." The New Yorker, pp. 72-80.

Magnuson, A. 1994. "After D-Day: Landfill Closure." MSW Management, 4(2):20-29.

Nesmith, L. December 1993. "Ready or Not, Construction Recycling is on the Way." Architectural Record, pp. 18-23.

O'Leary, P. and P. Walsh. "ALM Solid Waste Course \#C240." Internet (Originally published in Waste Age Magazine, January 1991 through March 1992.)

Peters, L. R. 1992. "Subtitle D Reference Guide. A Summary of the New Regulations." Golder Associates Inc., Atlanta, Georgia.

Poore, P. "Is Garabage an Environmental Problem?" Garbage. November/December 1993, pp. 40-46. 
Steuteville, R. and N. Goldstein. 1993. "The State of Garbage in America." BioCycle, 34(5):42-50.

Steuteville, R. 1994. "The State of Garbage in America." BioCycle, 35(4):46-52.

Thomas, S. 1993. A Guide to Conducting a Buy-Recycled Campaign. Clean Washington Center. Exhibit 3.

Walsh, J. J., S. M. Hamilton, and W. G. Vogt. 1994. "Application of New Source Performance Standards at Typical Landfill, Implementation, Schedule, and Costs," pp. 1-14.

Zandi, I. 1991. "Major Issues Facing Solid Waste Management in the 1980s." Journal of Resource Management and Technology, 19(4):166-181.

\section{Government Publications}

40 CFR 258. 1991. U.S. Environmental Protection Agency, "Criteria for Municipal Solid Waste Landfills." U.S. Code of Federal Regulations.

Federal Register, May 30, 1991.

National Oceanic and Atmospheric Administration (Video). 1988. "Trashing the Oceans; Persistent Marine Debris."

National Renewable Energy Laboratory. "Data Summary of Municipal Solid Waste Management Alternatives." August 1992, pp. 1, 16.

Resource Conservation and Recovery Act (RCRA) of 1976. 42 USC 6901 et seq., as amended.

U.S. Congress, Office of Technology Assessment. 1992. Managing Industrial Solid Wastes from Manufacturing, Mining, Oil and Gas Production, and Utility Coal Combustion-Background Paper. OTA-PB-O-82, U.S. Government Printing Office, Washington, D.C.

U.S. Department of Energy. 1992. Office of Industrial Technologies. Energy from Municipal Waste Program, Program Plan. Washington, D.C.

U.S. Department of Energy. 1992. Annual Report to Congress on Federal Government Energy Management and Conservation Programs. DOE/CE-0343P, Washington, D.C., p. 1.

U.S. Environmental Protection Agency. 1986. "Asbestos Fact Book." A-107/86-002, Office of Public Affairs, Washington, D.C.

U.S. Environmental Protection Agency. 1988. "Solid Waste Disposal in the United States." EPA/530-SW-88-011, Office of Solid Waste and Emergency Response, Washington, D.C.

U.S. Environmental Protection Agency. 1989. "Decision-Makers Guide to Solid Waste Management," EPA/530-SW-89-072, U.S. Government Printing Office, Washington, D.C. 
U.S. Environmental Protection Agency. 1991. "Unit Pricing. Providing an Incentive to Reduce Municipal Solid Waste." EPA/530-SW-91-005, Solid Waste and Emergency Response, Washington, D.C.

U.S. Environmental Protection Agency. 1992. "Characterization of Municipal Solid Waste in the United States: 1992 Update." EPA/530-S-92-019, U.S. Government Printing Office, Washington, D.C.

U.S. Environmental Protection Agency. 1993. "Air Conditioners and the Ozone Layer." EPA 430-F-93-006, Office of Air and Radiation, Washington, D.C.

U.S. Environmental Protection Agency. 1993. "Disposing of Appliances With Refrigerants." EPA/430/F-93/003, Office of Air and Radiation, Washington, D.C.

Washington State Department of Ecology. December 15, 1990. "Moderate Risk Waste, A Progress Report." Volume 2-1 of the Problem Waste Study, Publication \#93-45, Olympia, Washington.

Washington State Department of Ecology. July 1993. "1992 Washington State Waste Characterization Study." Volume 1: Executive Summary, Publication \#93-45, Olympia, Washington.

\section{Conference Proceedings}

Blackstock, T. H. and S. S. Tyson. May 1994. "Overview of Coal Ash Use in the USA--Green Products for the 21st Century." Presented at the Pollution Prevention Conference X, Denver, Colorado.

Friege, H. 1992. "Waste Incineration and Waste Management - The German Experience." In Waste Management: 9th World Clean Air Congress, Volume 1. Montreal, Quebec, Canada.

Section IU-2B.04

Karau, J. "Waste Management and the London Dumping Convention." In Waste Management: 9th World Clean Air Congress, Volume 1. Montreal, Quebec, Canada. Section IU.3-10.

Kocagoy, G. and K. Curi. 1993. "The Ümraniye-Hekimbasi Open Dump Accident." In Proceedings of 9 th International Conference on SW Management. Philadelphia, Pennsylvania. Section 2B.

Jockel, W. 1992. "Flue Gas Emissions of Organic Compounds from Waste Incinerators." In Waste Management: 9th World Clean Air Congress, Volume 1. Montreal, Quebec, Canada.

Section IU-4A.04

Rahman, M. H. "Impact of Waste from Slum Areas on Environment in Greater Dhaka City." In Proceedings of 8th International Conference on SW Management and Secondary Materials. Philadelphia, Pennsylvania. Section 1D. 
Tent, J. 1992. "Emissions and Emission Control at Landfill Sites." In Waste Management: 9th World Clean Air Congress, Volume 1. Montreal, Quebec, Canada. Section IU-4A.10.

United Nations Conference on Environment and Development. July 22, 1994. "Report of the United Nations Conference on Environment and Development." Agenda 21. A/CONF.1561/26 (Volume II), pp. 15-26.

\section{Newspaper Articles}

Appel, T. May 23, 1994. "Industry Braces for Increased Pressure Under EPA's Re-Evaluation of Dioxin." The Wall Street Journal, p. A9A.

Barrett, P. M. April 5, 1994. "High Court Rules States Can't Impose Higher Fees on Out-of-State Garbage." The Wall Street Journal.

Bailey, J. April 26, 1994. "Recycling Mania Crashes and Burns in California." The Wall Street Journal, p. B1.

Oliver, C. June 21, 1994. "Disposing of America's Garbage, Is Mandated Recycling All It's Cracked Up To Be?" Investor's Business Daily, pp. 1-2.

\section{Newsletters}

Solid Waste Report. May 5, 1994. "Supreme Court: RCRA Fails to Exempt All MWC Ash from Hazwaste Regulation," p. 145.

Solid Waste Report. May 12, 1994. "EPA Says Fetuses Immune Systems Are Main Targets of Dioxin Threat," p. 153.

Solid Waste Report. 1994. "Industrial Waste Landfills Attempt to Offer Cost Savings, Security," p. 223.

\section{Company Brochures}

Weyerhaeuser. 1992. "Recycling - And Beyond." (Information Bulletin). BC 373 10-92.

Sanifill. 1992. Sanifill 1992 Annual Report. Houston, Texas. (J. Chris Brewster, President).

\section{Phone Calls}

Nedrow, M. July 20, 1994. Telecommunication. Yakima County Public Works. 
Appendix A

Glossary 


\section{Appendix A}

\section{Glossary}

Biodegradable Material

Bottle Bill

Collectively Managed Solid

Waste

Combustible

Commercial Solid Waste

Composting

Construction, Demolition and Landclearing (CDL)

Disposal

Energy Recovery
Material which can be broken down by microorganisms into simple, stable compounds such as carbon dioxide and water. Most organic wastes such as food wastes and paper are biodegradable.

A law requiring deposits on beverage containers.

Wastes collected from a number of sources for management as a collective group; e.g., Municipal Solid Waste.

Various materials in the solid waste stream which can be burned, such as paper, plastic, lawn clippings, leaves, and other organic materials.

All types of solid waste generated by stores, offices, restaurants, warehouses, and other non-manufacturing activities, excluding residential and industrial wastes (40 CFR 258).

The controlled biological decomposition of organic solid waste materials under aerobic conditions. The resulting material can be used as a soil amendment or mulch.

Materials resulting from landclearing, construction, remodeling, repair or demolition of buildings, bridges, pavements and other natural or anthropogenic structures (U.S. EPA).

The discharge, deposit, injection, dumping, spilling, leaking, or placing of any solid waste into or on any land or water so that such solid waste or any constituent thereof may enter the environment or be emitted into the air or discharged into any waters, including ground waters (RCRA).

A form of resource recovery in which the combustible portion of the solid waste is used as a fuel to produce some form of usable energy, such as steam or electricity. 
Heavy Metal

Household Waste

Hazardous Household Waste
Hazardous elements including cadmium, mercury, lead and other metals which may be found in discarded items such as batteries, lighting fixtures, colorants, and inks.

Any solid waste (including garbage, trash, and sanitary waste in septic tanks) derived from households (single and multiple residences), hotels and motels, bunkhouses, ranger stations, crew quarters, campgrounds, picnic grounds, and day-use recreation areas (40 CFR 258).

Waste derived from households, hotels and motels, bunkhouses, ranger stations, crew quarters, campgrounds, picnic grounds, and day-use recreation areas that is legally defined as hazardous per RCRA regulations.

Independently Managed Solid Wastes managed independently from collective waste management Waste systems, usually by the entity generating the waste or its agent; e.g., most industrial solid wastes.

Incinerator

A facility for the controlled burning of a waste material, such as MSW (see also Waste-to-Energy). This term is usually used for reference to facilities that do not recover useful energy from the burning of the waste materials, as opposed to Waste-to-Energy facilities.

Industrial Solid Waste (ISW) Solid waste generated by manufacturing or industrial processes that is not a hazardous waste regulated under subtitle $C$ of RCRA. Various types of industrial, agricultural, and mining wastes are considered ISW.

Onsite facilities where solid industrial wastes are placed in or on the land for permanent disposal.

Carbonless waste composed of matter other than plant or animal.

Waste materials originating in schools, hospitals, prisons, research institutions and other public buildings.

A practice of using several alternative waste management techniques to manage and dispose of specific components of the solid waste stream. The waste management alternatives include source reduction, recycling, composting, energy recovery, and landfilling. 
Land Application Unit

Landfill

Leachate

macro

Materials Recovery Facility

(MRF)

Moderate Risk Waste (MRW) and waste from businesses that fall under small quantity generator

Municipal Solid Waste

Putrescible Waste

Recovered Material

Recycling (SQG) status.

An area of land where solid wastes are applied on or incorporated into the soil for beneficial use or as a means of waste treatment and disposal. (Also termed land treatment, land farming, or land spreading.)

A facility for the disposal of solid waste materials by burying them under a shallow layer of cover material. See also "Sanitary Landfill" and "ISW landfill."

Liquid resulting from percolation through a waste site or matrix, and containing various soluble and insoluble constituents from the waste.

Large-scale, and/or global and/or long-range, with reduced attention to detail, as contrasted with micro.

A sorting, baling, and distribution facility for collected recyclable materials.

As used in this report, any solid waste managed collectively by and/or for a municipality, excluding certain types of waste, such as construction or demolition debris and automobile scrap.

Solid wastes which are capable of being decomposed by microorganisms with sufficient rapidity to cause nuisances from odors or gases and capable of providing food for, or attracting, animals and disease vectors.

Waste material and byproducts which have been recovered or diverted from solid waste, but not including those materials and byproducts generated from, and commonly reused within, an original manufacturing process.

The reintroduction of a material back into the process by which it was formed. In common usage, recycling means using discarded or waste materials and objects in original or reprocessed form. Commonly recycled materials from municipal solid wastes include newspaper and other paper products, aluminum, glass, some types of plastic, steel and other metals. Efforts are also under way to recycle various materials 
from other solid waste sources such as aggregates and wood fibers from construction debris, and various kinds of materials from industrial wastes.

Refuse-Derived Fuel (RDF) Fuel produced by processing waste materials into a form for more efficient combustion in waste combustion plants or as supplemental fuel or as a replacement for other fuels.

Reuse

The use of a product more than once in its original form, for the same purpose.

Runoff

Aqueous surface releases from a site resulting from precipitation on the site, which may include leachate or other pollutants as a result of contact with materials or wastes on the site.

Sanitary Landfill

A facility for the land disposal of solid waste that meets applicable criteria (e.g., RCRA section 4004). Waste is spread in thin layers, compacted, and covered with a fresh layer of soil each day to minimize pest, aesthetic, disease, air pollution, and water pollution problems. Current regulations for new landfills also require liners and leachate/gas collection systems.

Solid Waste

"Any garbage, refuse, sludge, from a waste treatment plant, water supply treatment plant, or air pollution control facility and other discarded material including solid, liquid, semisolid, or contained gaseous material resulting from industrial, commercial, mining, and agricultural operations, and from community activities, but does not include solid or dissolved material in domestic sewage, or solid or dissolved materials in irrigation return flows or industrial discharges which are point sources subject to permits under section 402 of the Federal Waste Pollution Control Act, as amended (86 Stat. 880), or source, special nuclear, or byproduct material as defined by the Atomic Energy Act of 1954, as amended (68 Stat. 923)." (RCRA). For this report, we have not included any liquid or sludge wastes.

Solid Waste Management

The systematic administration of activities which provide for the collection, source separation, storage, transportation, transfer, processing, treatment and disposal of solid waste. 
Source Reduction

Superfund

Sustainable Development

Waste Pile

Waste-to-Energy (WTE)

White Goods

Yard Wastes
A process or opportunity applied at the beginning of a manufacturing process or purchase decision, with the purpose of preventing or minimizing generation of wastes and/or substituting less toxic or hazardous materials for more environmentally detrimental materials.

Also known as CERCLA (i.e., the Comprehensive Environmental Response, Compensation and Liability Act of 1980). Superfund provides a federal response to uncontrolled releases of hazardous substances from a vessel or from any onshore or offshore facility, through a scheme of strict liability imposed upon a broad class of potentially responsible parties, backed up with other funding. (Superfund Manual, 3rd Edition, 1988).

The concept that economic development should be carried out in such a way that it can be sustained in the same manner over long periods of time without sacrificing natural resources or the environment for short-term gain. As applied to solid waste, this concept would require that solid waste management practices be carried out in a manner that is sustainable over the long-term.

A mass or pile of industrial solid non-flowing waste material that can function as a treatment or storage site.

A strategy of using waste materials, either directly or RDF to replace conventional fuels in energy production.

Large household appliances such as refrigerators, air conditioners, freezers, stoves, washing machines, and the like.

Leaves, grass clippings, prunings, and other natural organic matter from yards, gardens, parks, campgrounds, etc. Yard waste may also include stumps and brush, but these materials are not normally handled at composting facilities. 
Appendix B

Acronyms 


\section{Appendix B}

\section{Acronyms}

\begin{tabular}{|c|c|}
\hline BAT & Best Available Technology \\
\hline BTU & British Thermal Units \\
\hline CAA & Clean Air Act \\
\hline $\mathrm{CDL}$ & Construction, Demolition and Landclearing Waste \\
\hline CERCLA & Comprehensive Environmental Response, Compensation and Liability Act \\
\hline CFC & Chlorofluorocarbon \\
\hline CFR & Code of Federal Regulations \\
\hline CMSW & Collectively Managed Solid Waste \\
\hline CWA & Clean Water Act \\
\hline DIY & Do-It-Yourself \\
\hline DOE & U.S. Department of Energy \\
\hline EPA & U.S. Environmental Protection Agency \\
\hline HHW & Hazardous Household Waste \\
\hline HSWA & Hazardous and Solid Waste Amendments of 1984, amending RCRA. \\
\hline ISW & Industrial Solid Waste \\
\hline LDC & Less-Developed Countries \\
\hline MRF & Materials Recovery Facility \\
\hline MRW & Moderate Risk Waste \\
\hline MSW & Municipal Solid Waste \\
\hline MSWLF & Municipal Solid Waste Landfill \\
\hline MWC & Municipal Waste Combustion \\
\hline NMOC & Non-Methane Organic Compounds \\
\hline NREL & National Renewable Energy Laboratory \\
\hline NSPS & New Source Performance Standards \\
\hline NPL & National Priorities List \\
\hline OIT & Office of Industrial Technology (DOE) \\
\hline OSHA & Occupational Safety and Health Act \\
\hline PCB & Polychlorinated Biphenyl \\
\hline POTW & Publicly Owned Treatment Works \\
\hline RCRA & Resource Conservation and Recovery Act \\
\hline R\&D & Research and Development \\
\hline RDF & Refuse-Derived Fuel \\
\hline SDWA & Safe Drinking Water Act \\
\hline SQG & Small Quantity Generator (of Hazardous Waste) \\
\hline VOC & Volatile Organic Compound \\
\hline
\end{tabular}


Appendix C

Moderate Risk Waste 


\section{Appendix C}

\section{Moderate Risk Waste}

Moderate risk waste (MRW) is a category of solid waste that is beginning to be managed with a higher priority. In the U.S., this waste includes both household hazardous waste (HHW) and the waste from businesses that fall under small quantity generator (SQG) rules because they do not generate more than $100 \mathrm{~kg}$ per month of waste and they treat their waste as if it were non-hazardous. The rules allow it to be included in garbage pickup from a residence and deposited in a normal MSW landfill site. Small business is allowed to be an unpermitted generator and excused from a number of the more stringent reporting requirements; however, these wastes must be managed by small business as if they were a permitted generator. There have been incidents where these rules have led to problems for both the landfill accepting the MRW and for the haulers of the waste. More industrialized countries such as those in western Europe, Japan, and South Korea are concerned about these wastes and are collecting them outside the regular MSW stream in ways similar to the U.S.

These wastes have been of particular concern where they have caused problems. An incident in the San Francisco Bay Area where a garbage truck caught on fire was blamed on the HHW, specifically chlorine pool tablets, that was mixed with household garbage. A landfill site in north Spokane, Washington, is on the Superfund list because of groundwater contamination which has been blamed on MRW deposited in the landfill.

Large municipalities are more concerned with MRW than rural areas. Some large cities have programs for collection because of local concerns and not because of regulatory mandates. Incinerators of MSW are routinely concerned about the presence of MRW in the waste stream because the heavy metals from batteries become part of the ash remaining after incineration.

The state of Washington has an aggressive campaign to manage MRW. Every county in Washington has been required to develop a plan to manage these wastes. Some smaller counties have developed their plans in conjunction with a neighboring county. In the case of one county in southeast Washington the plan includes a county from neighboring Idaho. These plans outline the process that will be used to collect and monitor wastes in this category. Most counties are going to establish fixed facilities for their collection which will be open on a regular basis for drop off by local residents. The other counties are either using mobile collection units at various locations on a rotating basis or are publicizing local collection events which may be held just once a year or several times per year at particular locations in the county. 
At these collection events or sites, residents will bring their waste in an appropriate container for drop off. No questions are asked and at most only general survey information is collected. For the SQG there is no cost for the disposal of their waste when brought to the drop off site. Some counties require them to pre-register their intention to use the drop off for disposal of waste or it will not be accepted.

The Washington State Department of Ecology funds these collection sites and events, reimbursing the counties for the labor and contractor costs of holding the collection events and disposing of the wastes that are collected. Washington State Initiative 97 imposed a fee on materials sold in the state which contain hazardous substances. These fees are collected on all products, including petroleum, and provide the means by which this program can be supported. The funds are dispersed on a per capita basis to each county. The counties are required to report annually to the Washington Department of Ecology on the events they hold, the number of participants and the amount of wastes collected. Survey results show that participants like the events and are willing to participate on a regular basis so that home storage is not necessary.

Waste characterization studies (Washington State Department of Ecology 1993) show that about $1 \%$ of the total amount of MSW is hazardous waste. This includes used motor oil, paints, solvents, cleaners, pesticides, herbicides, antifreeze, batteries, auto batteries, adhesives and other miscellaneous hazardous chemicals or medicines. The percent of hazardous waste from single family residence or multiple family residence sources is not significantly different(both about $1 \%$ ). The composition is different because single family residences produce more paint/adhesive and used oil waste then multiple family residences.

A survey from 1990 shows that $58 \%$ of the hazardous waste produced by households and SQG was not being properly disposed. Of the two sources, business tended to handle the waste properly more often than households (Washington State Department of Ecology 1990).

Used oil composes $50 \%$ overall of the waste disposed, of SQG only $12 \%$ do not dispose properly. However households dispose of oil improperly $64 \%$ of the time. This is by far the waste stream of most concern to regulators because it has the largest volume, and a large potential to pollute ground drinking water sources. Overall about $28 \%$ of used oil produced is going to unknown or improper disposal in Washington which has an active collection and education program. It is assumed that in other states where there is not such an active collection program, more of this waste stream is ending up in landfills or on the ground in the backyard.

Used oil is a concern because there is a significant volume produced by the Do-It-Yourself (DIY) home oil changers that is not showing up in the collection efforts. The concern is that these DIY are not properly disposing the oil but are either sending it to the landfill in garbage or by selfhaul, pouring down the publicly owned treatment works (POTW) sewer lines/storm drains or pouring down a hole in the back yard to dispose of the oil. This oil is toxic to aquatic animals and can potentially contaminate groundwater if disposed of improperly. Questions to a local POTW found 
that oil is not found in any quantity in the waste stream and that the regular processing of the waste stream finds no oil products in the effluent. The storm drain system does not connect to the POTW but drains directly into local waterways. It is not known where oil found in this system originates but is very small in total volume.

Oil collected at collection events and reported by SQGs exempt from reporting requirements is generally recycled in one of two ways. Some establishments (auto dealerships, oil changers) use the oil directly for heating, which is acceptable in heating units less than 500,000 Btu capacity. If the oil is not used onsite, it is collected by a commercial used oil hauler.

The used oil that is collected by commercial recycling haulers is usually purified by distillation and sold to marine shipping companies as bunker fuel for the boilers on the ship. When used in this way the material is unregulated and can be burned by ocean-going vessels without regard for any emissions.

The Clean Washington Center has investigated an alternative technology that will produce a fuel close in properties to $\# 2$ diesel. The product produced by this process has a lower flash point than \#2, contains a greater concentration of heavy metals such as cadmium, chromium, lead and arsenic as well as a higher sulfur content. The viscosity also is believed to be too high for use as a fuel in winter where it may not flow properly. The product is currently being used in Winnipeg, Alberta, Canada as a truck fuel during summer months and as a heating fuel by the University of Winnipeg during winter months. Modifications in the recycling process can remove the sulfur content and blending with regular fuel sources may attenuate the other negative contents. The main problems for the process are the flashpoint of the fuel and viscosity issues. An ash cake that results from processing used oil has been found to pass toxicity tests and to be below regulatory levels for those tests conducted (Clean Washington Center 1993).

Lead-Acid vehicle batteries and paints are about equal in quantity and are the next most abundant waste streams. Used vehicle batteries constitute about $15 \%$ of the HHW-SQG waste stream. These lead-acid batteries contain a significant amount of sulfuric acid and lead salts which can cause significant ground or surface water contamination. The lead is present in both solubilized and solid forms. The solid forms can be leached by water over a long period of time into groundwater. When disposed in a landfill the usually plastic containment gets broken by compaction activities and the materials are free to become part of the landfill leachate. Most batteries are recycled by the consumer on an exchange basis with the retailer at the time of purchase. It has been found by survey that consumers that do not exchange batteries when purchasing a new one, tend to store the dead battery at their premises until disposal at some later time. In states that require exchange at the time of purchase, these batteries do not show up at collection events or in waste characterization studies at landfills. In Oregon, which has a mandatory exchange law, the only batteries turned in at hazardous waste collection events are those that homeowners have been storing in the garage or barn and are not the result of a recent new purchase. 
Paints, adhesives and paint thinner are also about $15 \%$ of the hazardous waste stream. Latex paints can be allowed to dry either by application to waste paper or open container air drying, or mixed with cement to form a solid. The resulting materials are disposed of by landfill. These materials are usually inert and do not pose a significant risk of leachate formation or ground contamination.

Oil based paints and solvents must be handled in a different manner. The organic solvents are highly flammable, volatile and are a health and fire hazard. The usual disposal method is for these wastes to be properly packaged and sent to either a permitted hazardous waste incinerator or a permitted hazardous waste landfill for proper disposal. Air evaporation of the paint or solvent is not permitted by clean air rules because these organic solvents are an important contributor to smog and ozone formation in the atmosphere.

Antifreeze from automobiles/trucks constitutes approximately $6.5 \%$ of the overall hazardous waste stream with households and SQG contributing about equal amounts. Again households dispose of this material improperly most of the time, but this is one area where SQGs also do not dispose of properly half of the time. The ethylene glycol in antifreeze is completely recyclable at low cost and can be reused without difficulty. Commercial haulers will pick up the used antifreeze and sell the rerefined product to a garage or dealer in bulk for a price lower than new antifreeze. The homeowner/DIY commonly allows the material to spill on the ground or street with no effort at collection. This material will pollute groundwater or streams and is toxic to both land and aquatic animals. It has a sweet taste and causes severe burns of mucous membranes on contact. As educational efforts have increased, more of this waste stream is being collected and recycled.

Cleaners for buildings and households are about $5 \%$ of the wastes and are disposed of improperly $80 \%$ of the time. These cleaning products may contain ammonia, caustic soda or potash, phosphates, solvents, etc., all of which can cause problems if not handled properly. Mixing cleaning products can produce toxic gases such as phosgene which are highly toxic and very dangerous in an enclosed environment. These materials are not considered hazardous by most individuals because of their common use in the household, and their advertisement and sale in grocery stores. The hazardous nature for some products may not come until mixed with other materials or cleaners. Common bowl cleaners when mixed with other cleaners can produce chlorine or phosgene gas and have been known to cause severe injury or death when there is inadequate ventilation. These materials in the MSW stream can be mixed by container breakage or mixing with other materials present in the waste stream. The sewer line is the most common disposal method by SQGs and the garbage or self-haul to landfill the most common for a household.

Pesticides and herbicides constitute about $2 \%$ of the HHW stream and are disposed of properly only $33 \%$ of the time. Most excess product is placed in the garbage or hauled to the landfill site, little is reported as poured down the drain or on the ground. Even though the volume of these materials is small they are a significant hazard because of their concentration/toxicity and are commonly recognized as being highly dangerous. At a landfill site these materials can be a significant problem if present in large amount. The containment either deteriorates or gets broken, 
the liquid or solid then is mixed with surrounding materials either through physical mixing or leaching, which increases the volume of hazardous waste. If an extremely persistent or hazardous substance is discovered in a landfill site it must be removed and cleaned up, sometimes at great expense, before it can contaminate an even larger volume of the MSW present. In Yakima County, Washington, a deposit of pesticide was discovered in the landfill site from a previous use of the land as a disposal site. This pesticide was buried many years before the land was purchased for use as a county landfill, but its discovery required cleanup at a cost in excess of $\$ 200,000$ (telephone communication from Mr. Mark Nedrow, Yakima County Public Work, 7/20/94). Educating the public on proper disposal of these compounds is important, for the cost to clean up a contaminated landfill site can far exceed the cost of an education campaign to prevent the release in a landfill of pesticides or herbicides. These substances will become part of the leachate from the landfill and have a great potential for groundwater contamination.

Other hazardous materials (about 5-7\%) that are included in the MRW category generated by households and SQGs are acids, bases, swimming pool chemicals, solvents, paint removers, dry cell batteries, aerosol cans, PCB solids and liquids, and asbestos. All of these materials are by nature dangerous if handled improperly. Because of the way they are sold or used some are not considered by the user as significantly hazardous. The problems arise when hazardous materials are placed in the waste stream and become mixed with other materials with which they are not compatible. A common swimming pool chlorinating compound containing calcium hypochlorite can ignite organic material. This has been determined to be the cause of the garbage truck fire near San Francisco. Dry cell batteries may contain silver, mercury, zinc, cadmium or nickel. These metals are released when the containment of the battery is breached by compaction or corrosion in a landfill. The metals are then leached into the ground or found in the leachate collected by the landfill. Efforts are being made to remove heavy metals from these batteries. By the end of 1995 batteries will no longer contain mercury. Aerosol cans are an explosion hazard at the landfill. PCBs are found in liquid filled capacitors used on electric motors and in the lubricating oil found in some air conditioners. PCBs are persistent and accumulate in the fatty tissue of living organisms. When leached from a landfill they will accumulate in fish and wildlife that feed on aquatic organisms. Paint removers contain the solvent dichloromethane which by laboratory testing has been shown capable of dissolving some of the plastic materials used as a liner required under modern landfills. This has the potential to put a hole in the liner through which leachate can flow into the ground and potentially damage groundwater beneath the landfill site.

In LDCs, unless efforts are made to collect them by the government, it is assumed that MRW materials become a part of the MSW stream and end up being deposited in a landfill. Because of the common scavenging practices allowed at landfills in these less-developed countries, there is the potential to expose a large number of people to these hazardous materials. Also, LDCs tend to be located in climates that have a large amount of rainfall or flooding especially during a certain season of the year. Therefore, the leaching of hazardous substances into groundwater would be much higher in less-developed countries because of the lack of liners or leachate collection. 
In contrast to more developed nations, the MRW stream in less-developed countries would be expected to be different in composition and volume. Fewer automobiles would generate less used oil and lead-acid batteries. Different building practices and materials would generate less waste paint. Less-advanced technology would generate fewer expended batteries. As industrialization and modernization increases these wastes will increasingly become a larger percentage of the MSW stream. Education on proper disposal of MRW is a priority to prevent environmental contamination. Governmental awareness, regulation, and provision for collection is important and can provide funding by mechanisms similar to that of Washington State with a fee on producers and sellers of materials that have a hazardous content. 


\section{Distribution}

No. of

Copies

\section{OFFSITE}

12 DOE/Office of Scientific and Technical Information

S. A. Vigil, Professor

Civil and Environmental Engineering Department

California Polytechnical State University

San Luis Obispo, CA 93407

J. C. DiBari

223 Lookout Point Dr.

Selah, WA 98942

P. J. Carpenter

9107 236th SW

Edmonds, WA 98026

\section{ONSITE}

DOE Richland Operations Office

D. D. Green
No. of

Copies

\section{$\mathrm{CH} 2 \mathrm{M}$ Hill Hanford}

D. C. Stapp

35 Pacific Northwest Laboratory

W. B. Ashton, BWO

J. E. Beck

M. M. Davis (5)

T. J. DeForest (5)

E. A. Flores

G. M. Holter (5)

J. A. Jaksch

P. S. Kaae

A. Khawaja

D. K. Kreid

T. L. Kuusinen

G. W. McNair

D. R. Payson

W. T. Pennell

K. L. Peterson

G. M. Stokes

J. S. Tixier

Publishing Coordination

Technical Report Files (5) 